\title{
A typology of tone and inflection: A view from the Oto-Manguean languages of Mexico
}

\author{
Enrique L. Palancar
}

\section{Introduction}

Tone is well-known for playing a role in the makeup of inflection, but the literature has not yet produced a comprehensive typology of the relation between tone and inflection from a morphological perspective. There are various reasons for this. On the one hand, the interest in the morphological side (i.e. the form) of inflection has lain outside the general spotlight of linguistic typology, which, except for the Surrey Morphology Group, has been mainly concerned with trying to make sense of linguistic structure in functional terms. I show here that in most situations where tone is involved in inflection it is difficult, if not impossible, to give it a clear-cut morphosyntactic function.

On the other hand, our understanding of how tone works is relatively recent and the emphasis of its study has been on its phonological nature and on how it contributes to the creation and maintenance of lexical meaning. This understanding has been made possible thanks to the substantial body of knowledge generated through the laborious work of many field linguists describing tonal languages with complex inflection. In this respect, the contribution to the field has mainly come from the languages of Africa. We know less of languages from other areas, especially of those from the Americas because it has taken the field more time to gather the basic relevant information. This is somewhat ironic because Pike's 1948 seminal work on tone was precisely inspired by the Oto-Manguean languages; a large phylum of tonal languages spoken in Mexico.

In this light, I outline here a typology of the ways we find tone involved in the realization of inflectional categories. For this, I take a morphological perspective on tone. This also means that I have consciously avoided using jargon from the discipline of phonology since its technicalities often hinder the understanding of a broader readership. This also means that the emphasis is not on what a given tone sounds like or how it stands, works or should be characterized with respect to other suprasegmental units in the system, but rather on what tone is used for in the formal makeup of inflection and on how it is used for that purpose.

In this respect, because inflection is the part of syntax that is relevant to the morphology, the emphasis will be on the mapping between linguistic form and grammatical meaning. To understand the role of tone in this context, we could imagine a continuum of two ideal systems. At the one end, tones have no role in inflection. They are regarded as a lexical property of an inflected stem or of a grammatical affix. At this end, tones are bits of the lexical phonology. This type of tone is presented in $\S 2$. At the other end, tones are treated as discrete suprasegmental affixes (commonly called 'auto-segments') working as genuine exponents of morphosyntactic feature values. Such type of inflectional tone is briefly presented in $\S 3$. Languages vary considerably along this logical continuum and the present study is an attempt to pinpoint the most relevant types that can be observed focusing on morphological tone which is a type of inflectional tone used as a building block of the grammar of a language for the construction of forms in inflectional paradigms. In this respect, in $\S 4 \mathrm{I}$ introduce the four main subtypes of morphological tone. Besides morphological tone, we can also find tonal allomorphy organized in inflectional classes. This type is presented in $\S 5$. 
To illustrate this typology I mainly focus on the Oto-Manguean languages of Mexico (although not exclusively). There are various reasons for this. Within Oto-Manguean, one finds the most complex morphological systems we know of (only comparable to some found among the Nilotic languages of Africa, notably Dinka and Nuer) and a great part of that complexity is due to tone. Also their internal diversity displays a great wealth of possible types. I also concentrate on verbal inflection, not only because verbs are by far the word class in these languages where the morphology is more complex, but also because we know less about the nominal inflection, whose study would no doubt have some bearing on the present proposal.

\subsection{The Oto-Manguean languages of Mexico}

Oto-Manguean (also 'Otomanguean') is a linguistic phylum of Amerindian languages spoken in Central and Southern Mexico. ${ }^{1}$ Oto-Manguean is typologically unique in the Americas because it is the only phylum where all its languages are tonal.

The 2005 census by the INALI ${ }^{2}$ states there are 1,769,971 speakers of Oto-Manguean languages, of which 218,679 are monolingual. Oto-Manguean consists of the eight different linguistic groups in Figure 1, which for the present purposes I treat as branches of the phylum. $^{3}$

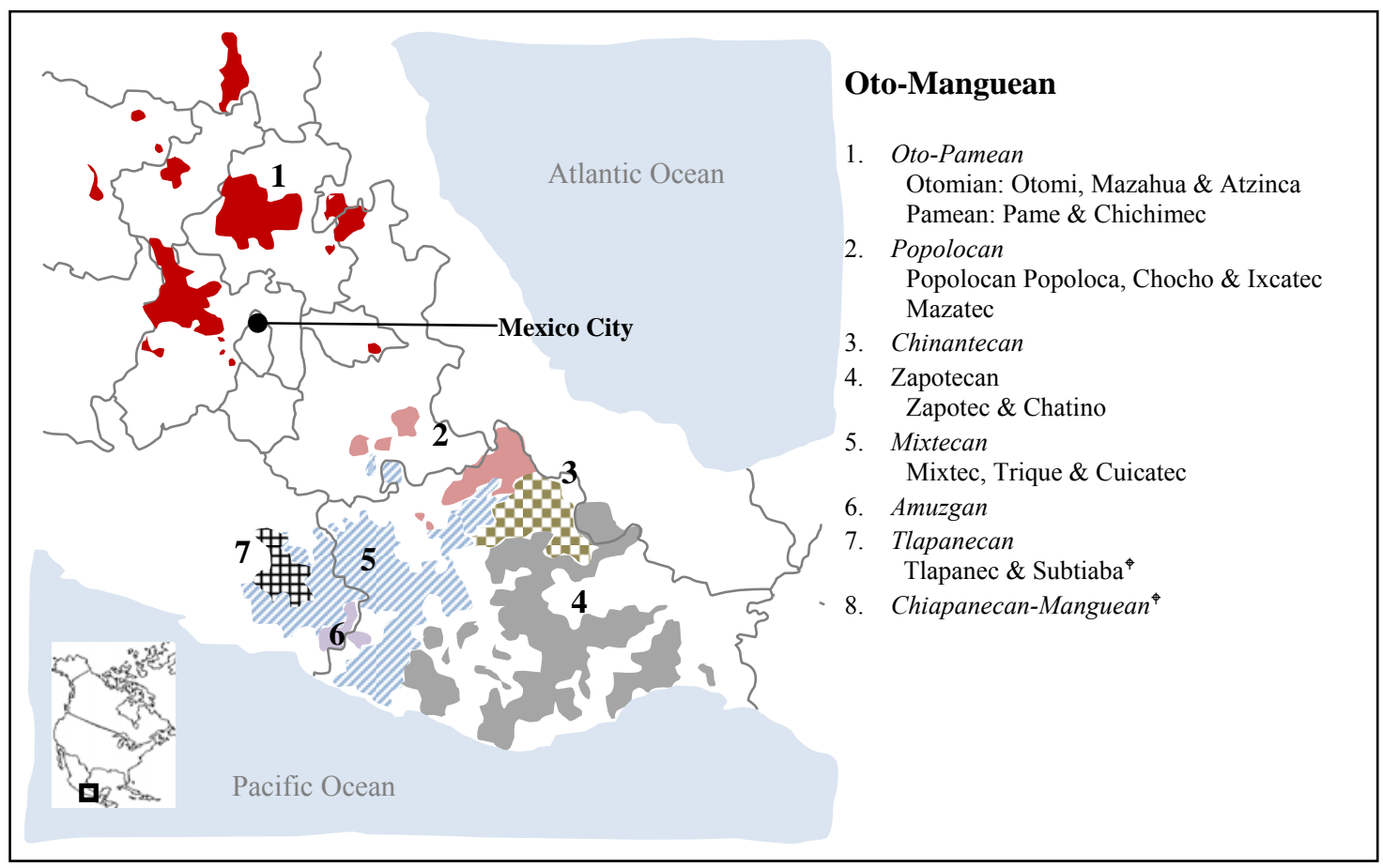

Figure 1. The Oto-Manguean languages of Mexico.

\footnotetext{
${ }^{1}$ The three Oto-Manguean languages once spoken outside the current territory of Mexico are Subtiaba (Nicaragua) (Tlapanecan), Monimbo ${ }^{థ}$ (Nicaragua) and Chorotega ${ }^{\uparrow}$ (Costa Rica) (Manguean).

${ }^{2}$ National Institute for Indigenous Languages.

${ }^{3}$ The traditional taxonomy found in Campbell (1997), which is in turn based on unpublished materials by Terrence Kaufman, proposes four major branches organized into two large subgroups: (i) Western Oto-Manguean consisting of Oto-Pamean-Chinantecan and Tlapanecan-Manguean; and (ii) Eastern Oto-Manguean formed of Amuzgo-Mixtecan and Popolocan-Zapotecan. I prefer to take here a flat approach to the phylum since this taxonomy has not yet been discussed at length. Coincidentally, Cecil H. Brown and Eric Holman supplied to me in a personal communication a MDS plot using data available at the Automated Similarity Judgment Program database (http://asjp.clld.org/). This plot shows that the superordinate groups of the traditional taxonomy lack a centered core and Western Oto-Manguean has no integration.
} 
While there is agreement among scholars as to which languages are Oto-Manguean and which are not, there is currently no established consensus regarding the number of languages involved. This is because Oto-Manguean generally involves important diasystems or dialectal continua within each of its different branches, making it difficult to define categorically where a given dialect finishes and a different language starts. Figures vary from source to source: while the Ethnologue and the Glottolog propose 176 and 179 different languages, respectively, the INALI proposes 220 giving more weight to sociolinguisitic factors (in much the same vein as Danish and Norwegian Bokmål or Serbian and Croatian are treated as different languages).

All Oto-Manguean languages are tonal. But the tonal systems within the phylum vary enormously; from languages with an inventory of two tones (e.g. Chichimec and Pame from the Oto-Pamean branch) to languages with an inventory of ten or more tones (e.g. the Eastern Chatino languages of the Zapotecan branch). Apart from tone, the internal diversity of the phylum makes it difficult to come up with an inventory of features that is shared by all languages. There is an overwhelming tendency towards open syllables, especially at root level. Languages often have nasal vowels, complex phonation and voice quality. All languages are head-marking. Nouns do not inflect for case, although they may receive classifiers and their possession inflection can be at times challenging. In some branches, the animacy value or the discourse status of a noun is also relevant for the inflection. OtoManguean languages lack non-finite forms such as infinitives, and this has consequences for the syntax of clause chaining. In general, inflectional morphology is very intricate. This is partly due to the interaction of multiple systems acting independently of each other, resulting in cross-classification: e.g. a verb may simultaneously belong to various inflectional classes: one for its endings, another for its stem changes and a third for its tonal changes. This situation produces in turn the great deal of irregularity in verbal paradigms that is characteristic of some branches (Levy 1987). At the level of word order syntax, all branches can be characterized as verb initial (also a Mesoamerican feature according to Campbell et al. 1986); only recently some have become predominantly SV. Oto-Manguean languages are largely fusional; they do not have noun incorporation except for the basic type. Their derivational morphology is largely unproductive. New words are often borrowed and often lie outside the scope of the more morphological aspects of the inflection.

\section{Tone as a phonological property of grammatical markers}

Inflectional information is often, although not exclusively, conveyed by affixes. In many tone languages with relatively complex inflectional morphology, tone may be simply a property of the lexical phonology of the inflectional affixes, just as it is associated with the phonology of other words with lexical content.

For example, Otomi languages (Oto-Pamean) have three tones, but only two are relevant for our purposes: high (represented with an acute accent) and low (not represented). A contrast based on the high vs. the low tone operates as a useful mechanism to keep grammatical markers phonologically distinctive, which would otherwise be segmentally homophonous. This is illustrated in (1) from the variety of Northern Otomi spoken in San Ildefonso Tultepec in the state of Querétaro. Here the tonal contrast of high vs. low that serves to create minimal pairs for lexical words (e.g. 'bóts'e $(\mathrm{H})$ 'religious offering' vs. 'bots'e (L) 
'basket, ribcage'; dó'yo (H) 'bone' vs. do'yo (L) 'hotplate to heat tortillas', etc.) is exploited in inflectional clitics dá vs. dà or gí vs. gì.
Tone $/ \mathrm{H} /$
Tone /L/
a. dá $=$ tsot'e
$\mathrm{da}=$ zot'e
1.CPL $=$ arrive.there
3. $\mathrm{IRR}=\mathrm{SS} /$ arrive .there
'I arrived there.'
'S/he'll arrive there.'
b. gí=tsot'e
2.INCPL $=$ arrive.there
gì $=$ tsot'
'You arrive there.'

The Otomi case is commonly found across languages, and it is the most common source for inflectional tonogenesis. In this respect, Palancar et al. (this volume) and Feist and Palancar (this volume) show cases in Mixtecan languages where a given grammatical prefix consisting of segments and tone loses its segmental part and all that remains of it is its tone, which then becomes the exponent of the grammatical information. Such tones need to be linked to a segment in the stem, and often invade its lexical phonology giving rise over time to complex tonal patterns (such as for example the tonal classes in $§ 5$ ).

\section{Morphosyntactic tone}

Tones can do things other than sit inert in the phonology. In Otomi languages, a third person possessor is encoded by a floating high tone. This happens without exception every time the information is required by the syntax. The high tone lands on the mora immediately preceding the possessed noun. ${ }^{6}$ The landing site may be a determiner as in (2a) or a preposition as in (2b) (in the examples, the singular enclitic $=r$ does not bear tone). ${ }^{7}$ The Otomi case also serves as an illustration that within the same inflectional system one may also find different situations at the same time.

(2) Possessed

$\begin{array}{ll}\text { a. } & \text { nó }=\mathrm{r} \\ & <3 . \mathrm{POSS}>\text { DEF.SG }=\mathrm{SG} \\ & \text { 'His/her/their child.' } \\ \text { b. } & \text { ká }=\mathrm{r}\end{array}$

$<3$.POSS $>$ on $=$ SG

'On his/her/their table.'
Non-possessed

$\begin{array}{lll}\text { bötsi } & \text { no=r } & \text { bötsi } \\ \text { child } & \begin{array}{l}\text { DEF.SG=SG } \\ \text { 'The child.' }\end{array} & \\ \text { méxá } & \text { ka=r } & \text { méxá } \\ \text { table } & \text { on=SG } & \text { table } \\ \text { 'On the table.' }\end{array}$

'On the table.'

\footnotetext{
${ }^{4}$ The third tone is a raising tone that is not found in inflectional formatives, but only found in lexical roots. This contour tone emerged from the monosyllabification of historical disyllabic stems bearing the melody /L-H/. This is a well-known source of lexical tonogenesis.

${ }^{5}$ Inflectional tonogenesis can also arise in unpredictable ways, see for example Fedden (this volume) for a very interesting case study of how a particular tone value in Mian, a Papuan language with a rich tonal system, serves an inflectional function in a very restricted context.

${ }^{6}$ If the mora on which the floating tone lands has high tone (for independent reasons it is not possible that it has rising tone), the word is pronounced with a rising tone that starts very high.

${ }^{7}$ Abbreviations: ANT anterior; AOR aorist; CPL completive; DEF definite; FIN final vowel; FUT future; HAB habitual; IMM immediate; IMPER imperative; IMPF imperfect; INCPL incompletive; INF infinitive; IRR irrealis; NEG negative; POSS possessive; POT potential; PROG progressive; PROSP prospective; PRS present; PST past; SUB subject; REC recent; SEQ sequential; SS secondary stem.
} 
The tone inventory of Otomi languages used for situations like this is restricted to a binary contrast of high vs. low. A more interesting case is found in Yoloxóchitl Mixtec, a language with more tones.

Yoloxóchitl Mixtec (Mixtecan) has nine basic tones in lexical contrasts (cf. Vietnamese has six according to the common view): four level tones (written with superscript numbers from $/ 1 /$ for the low tone through $/ 4$ / for the high tone); three rising tones $(13,14,24)$ and two falling tones $(32,42)$ (DiCanio et al. 2012). Out of these nine tones, at least three are fully exploited in the inflection. Table 1 illustrates the forms of different verbs for the irrealis, the negative irrealis and the completive. For this language, the tones in the irrealis can be taken as basic; that is, as provided by the lexicon (see Palancar et al., this volume).

Table 1. Tone and verbal inflection in Yoloxóchitl Mixtec.

\begin{tabular}{lllll}
\hline IRR & NEG. IRR & CPL & & \\
\hline $\mathrm{nu}^{3} \mathrm{mi}^{3}$ & $\mathrm{nu}^{14} \mathrm{mi}^{3}$ & $\mathrm{nu}^{13} \mathrm{mi}^{3}$ & 'hug' & (tr) \\
$\mathrm{ku}^{3} \mathrm{u}^{3}$ & $\mathrm{ku}^{14} \mathrm{u}^{3}$ & $\mathrm{ku}^{13} \mathrm{u}^{3}$ & 'happen' & (intr) \\
$\mathrm{nda}^{3} \mathrm{kin}^{2}$ & $\mathrm{nda}^{14} \mathrm{kin}^{2}$ & $\mathrm{nda}^{13} \mathrm{kin}^{2}$ & 'sharpen' & (tr) \\
$\mathrm{ku}^{3} \mathrm{ya}^{3} \mathrm{tin}^{3}$ & $\mathrm{ku}^{14} \mathrm{ya}^{3} \mathrm{tin}^{3}$ & $\mathrm{ku}^{13} \mathrm{ya}^{3} \mathrm{tin}^{3}$ & 'get closer' & (intr) \\
$\mathrm{ndu}^{3} \mathrm{to}^{3} \mathrm{ni}^{3}$ & $\mathrm{ndu}^{14} \mathrm{to}^{3} \mathrm{ni}^{3}$ & $\mathrm{ndu}^{13} \mathrm{to}^{3} \mathrm{ni}^{3}$ & 'open eyes' & (intr) \\
$\mathrm{nda}^{3} \mathrm{xi}^{3} \mathrm{i}^{4}$ & $\mathrm{nda}^{14} \mathrm{xi}^{3} \mathrm{i}^{4}$ & $\mathrm{nda}^{13} \mathrm{xi}^{3} \mathrm{i}^{4}$ & 'open' & (tr) \\
$\mathrm{cha}^{3} \mathrm{ka}^{3} \mathrm{ndu}^{4} \mathrm{u}^{4}$ & $\mathrm{cha}^{14} \mathrm{ka}^{3} \mathrm{ndu}^{4} \mathrm{u}^{4}$ & $\mathrm{cha}^{13} \mathrm{ka}^{3} \mathrm{ndu}^{4} \mathrm{u}^{4}$ & 'lay down' & (tr) \\
\hline
\end{tabular}

In table 1 , we have verbs with different melodies in the base form: /3-2/, /3-3/, /3-3-3/, /3-3-4/ and $/ 3-3-4-4 /$. If this form is compared with the tonal melodies of the other two forms, we observe there is a tone change affecting the first mora, i.e. instead of $/ 3 /$, we find $/ 14 /$ in the negative irrealis and $/ 13 /$ in the completive. The mapping of form (i.e., a specific tone value) and grammatical meaning (i.e., a specific inflectional value) is constant and there are no exceptions. This remarkable systematicity leaves us with an inflectional system operating with flawless morphosyntactic rules that involve tone. In such a system, tone could be said to work as a regular suprasegmental affix: the affix being suppletive for the negative irrealis (i.e. $/ 14 /$ replaces $/ 3 /$ on the first mora of the stem), or additive for the completive (i.e. $/ 1 /$ is inserted before the lexical $/ 3 /$ on the first mora of the stem producing a raising tone $/ 13 /$.

This regularity makes Yoloxóchitl Mixtec an ideal language for syntactic approaches to inflection that do not particularly appreciate the 'messy bits' of the morphology. But those bits exist, nonetheless; they sometimes mess about the mapping of form and meaning in the inflectional realization or they serve as mere building blocks in the formation of grammatical structure. Tone plays a fundamental part in those messy bits. In the following section, I outline the main types of purely morphological tone.

\section{Morphological tone: Tone linked to stems as a building block of paradigms}

To introduce morphological tone, let us first depart from a situation where tones are just an inherent property of the phonology of the stem, just as they may be of affixes (as in the Otomi case presented in \$2). In such a situation, stems surface with tones associated with them by the lexicon, just as they have specific vowels or consonants. ${ }^{8}$ In an inflectional system involving verbs, tone may sit inert on verbal stems. This may happen to all verbs, to only

\footnotetext{
${ }^{8}$ It is more convenient here to talk about stems rather than roots because the stem is the fundamental formal unit that represents the lexeme in an inflected form. Also, while some stems consist of a root only, some consist of other material besides the root.
} 
some or to just a handful of them. A particularly interesting case to start with is Tswana, a Bantu language spoken mainly in South Africa.

Tswana has two tones: high and low. The tones are lexically associated both with stems and with affixes. Stems can have inherent high tone or be toneless. If toneless, they are subject to complex prosodic rules at the word level (Creissels et al. 1997). Take for example the verb thalvхa - 'understand' which is a toneless stem that surfaces as /HLL/ in (3) as a result of a regular spreading rule by means of which the high tone of the preceding potential prefix $k a^{H}$ - spreads on to the first syllable of the stem; the other two syllables receive low tone by a prosodic default.

(3) $\mathrm{ba}^{\mathrm{H}}-\mathrm{ka} \mathrm{H}^{\mathrm{H}}-\mathrm{tq}^{\mathrm{h}} \mathrm{a}^{\mathrm{H}} \mathrm{lu} \mathrm{u}^{\mathrm{L}} \chi \mathrm{a}^{\mathrm{L}} \mathrm{n}-\mathrm{a}$

3.SUB-POT-understand-FIN

'They can understand.'

The issue at hand here is what Creissels (2006:10) treats as 'grammatical high tone'. In contrast to (3), in (4) the same toneless stem now surfaces as /LHH/ in the negative of the same mood. Here the high tones in the stem cannot be explained as the result of any prosodic rule, i.e. we might have expected the structure to have been /LLL/.

(4) $\mathrm{ba}^{\mathrm{H}}-\mathrm{ka}{ }^{\mathrm{H}}-\mathrm{sI}{ }^{\mathrm{L}}-\mathrm{tq}^{\mathrm{h}} \mathrm{a}^{\mathrm{L}} \mathrm{lu}{ }^{\mathrm{H}} \chi \mathrm{\chi a}^{\mathrm{H}} \mathrm{j}-\mathrm{I}$

3.SUB-POT-NEG-understand-FIN

'They cannot understand.'

Creissels concludes that the distribution of the high tone in (4) is purely morphological in nature (in the sense of Aronoff 1994), arguing that it does not respond to any semantically coherent bundle of morphosyntactic features values.

Verbal inflection in Tswana is rich. A verb can inflect for a large number of morphosyntactic values, including mood (indicative, circumstantial, subjunctive, imperative, potential, etc.), tense-aspect (present, future, perfect, etc.), polarity (positive vs. negative), disjunction (conjunct vs. disjunct), as well as non-finite forms such as the infinitive, the relative and the sequential. In this context, the grammatical high tone of Tswana is found in all negative forms, so in principle, one could take it to be an exponent of negation alongside other segmental ones (namely the prefix $\mathrm{sI}^{\mathrm{L}}-$ ), but it is also found in other forms that have little to do with negation, such as the positive indicative perfect conjunct, the positive circumstantial perfect, the imperative and the sequential. This heterogeneity of meanings indicates a lack of morphosyntactic function, but it does not mean it lacks a grammatical function altogether.

In our view, the grammatical tone of Tswana serves as a building block in inflected forms in paradigms. It works, as it were, like thematic vowels in languages like Latin or like stress patterns in Greek or Russian. We treat this type of tone as 'morphological tone'.

A very similar morphological tone system, but with a more complex distribution that requires an intricate morphophonological apparatus is found in Kabiyè, a Gur language of Togo that belongs to the North-Volta Congo subgroup of the Volta-Congo branch of Atlantic-Congo.

\subsection{Morphological tone conditioned by phonological shape}

Like Tswana, Kabiyè also has two tones: high (marked by an acute accent) and low (not represented). Verbs in Kabiyè have a rich array of inflectional possibilities, but to illustrate the point we will only concentrate on six basic forms built by suffixation (including zero 
suffixes, i.e. bare stems): imperfective present, imperfective past, past, aorist, infinitive and imperative (with a bare stem). There are verbs with inert tone across the paradigm, i.e. stem tone does not change, like for example kpézu 'forgive' in table 2.

Table 2. The Kabiyè verb kpéru 'forgive' has a stem with invariable tone.

\begin{tabular}{|c|c|c|}
\hline & 'forgive' & tone \\
\hline IMPF.PRS & -kpér-u & $\mathrm{H}$ \\
\hline IMPF.PST & -kpér-ar & $\mathrm{H}$ \\
\hline PST & -kpér-a & $\mathrm{H}$ \\
\hline AOR & -kpér & $\mathrm{H}$ \\
\hline INF & kper-u & $\mathrm{H}$ \\
\hline IMPER & kpér & $\mathrm{H}$ \\
\hline
\end{tabular}

But not all verbs in Kabiyè are like kpézu. For our analysis, we rely on the sample of 800 verbs in Roberts (2013). Out of them, only 165 behave like this; the rest have tonal alternations involving stems that receive a low tone in certain cells of the paradigm. What is interesting is that not all such verbs alternate in the same way.

All verbs considered, including the ones that do not alternate, display five patterns of tonal behavior. Table 3 shows two such patterns. Shading highlights stems that receive a low tone. Besides tone, stems may be also display other segmental changes that are independent of tone alternations.

Table 3. Two verbs in Kabiyè showing different patterns of tone alternations.

\begin{tabular}{|c|c|c|c|c|c|c|}
\hline & 'sweep' & tone & segm. & 'cut' & tone & segm. \\
\hline IMPF.PRS & 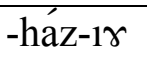 & $\mathrm{H}$ & haz & -cहk-1 & $\mathrm{H}$ & cek \\
\hline IMPF.PST & -haz-aŕ & $\mathrm{L}$ & haz & -cعk-aŕ & $\mathrm{L}$ & cek \\
\hline PST & -haz-aá & $\mathrm{L}$ & haz & $-c \varepsilon b-a$ & $\mathrm{~L}$ & $c \varepsilon b$ \\
\hline AOR & -ház-1 & $\mathrm{H}$ & haz & $-c^{\prime} \varepsilon$ & $\mathrm{H}$ & $c \varepsilon$ \\
\hline INF & haz-v́v & $\mathrm{L}$ & haz & cद́b-v & $\mathrm{H}$ & ceb \\
\hline IMPER & haz-1 & $\mathrm{L}$ & haz & $c \varepsilon$ & $\mathrm{L}$ & $c \varepsilon$ \\
\hline
\end{tabular}

Here we are interested in two important questions: (i) regarding the form: for the inflection of a given verb, can we predict when the stem will have a high or a low tone? and if so, how can we predict it? and (ii) regarding the function: what is the relation of tone to grammatical function in such a system? Let us address the first question.

The study of inflectional morphology is a quest to find grammatical structure and analyses are just possible paths to it. The standard procedure with tone is to take a given form as base, whose tone is considered lexical (i.e. stable and memorized), from which other forms are derived through morphophonological rules. This means that tone allomorphy may be predicted if one finds the key to the system that can make generalizations. Kabiyè is a good example of this.

Roberts (2013) divides Kabiyè verbs into 23 different conjugation models attending to other aspects of inflection, but not tone. ${ }^{9}$ The exemplar verbs for each one of Roberts' conjugations are given in table 4 together with an indication of their population size in his sample. To facilitate understanding, the forms in the table have been arranged in a slightly

\footnotetext{
${ }^{9}$ Roberts (2013) includes four other paradigms for another ten verbs with motion components and complex stems which we exclude here.
} 
different way to the way they appear in tables 2 and 3. Shading applies to cells with low tone stems. The different patterns of tonal behavior are indicated by roman numerals.

Table 4. Distribution of high vs. low tone in stems in Kabiyè verbal paradigms.

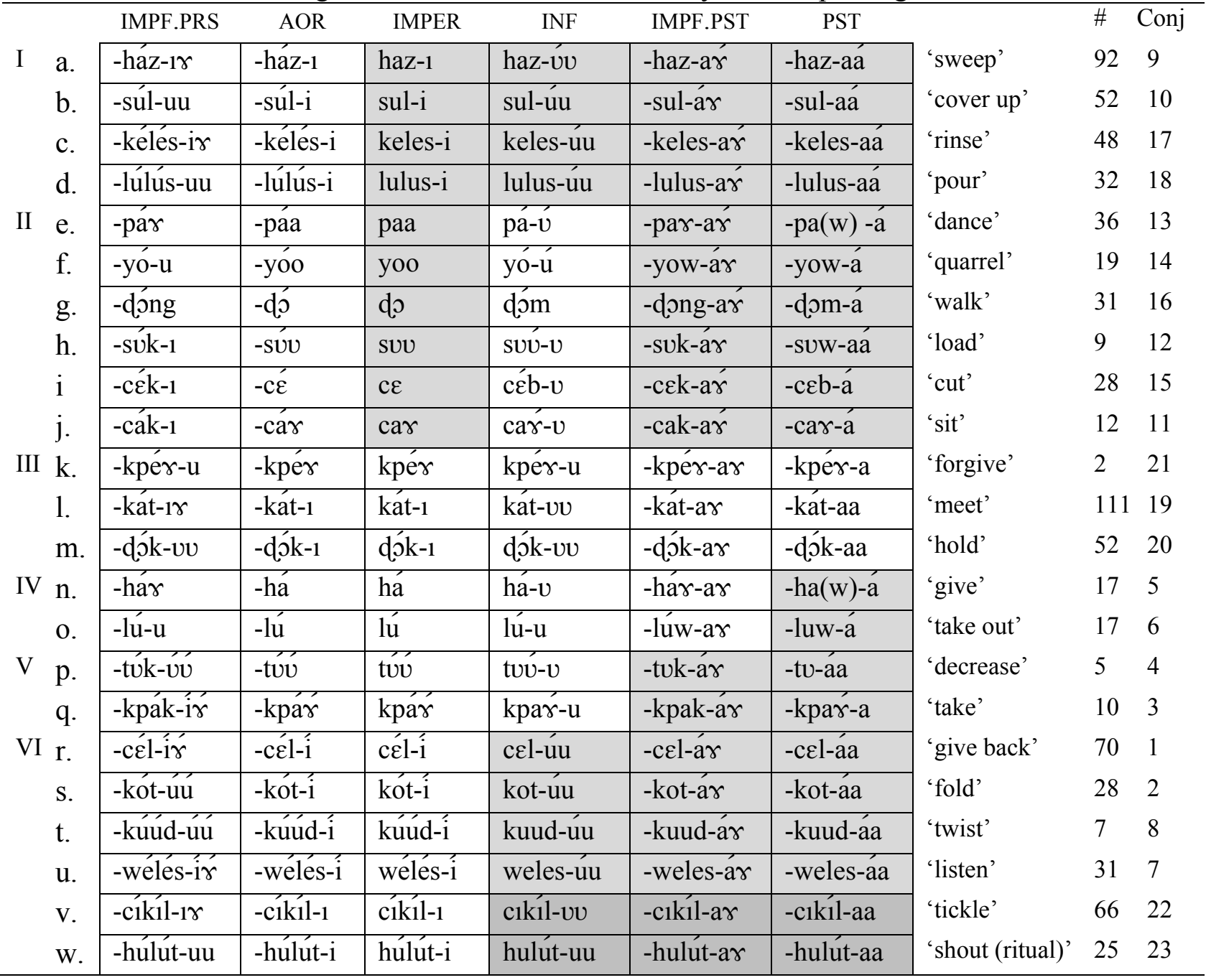

We observe that a high tone is always used for the imperfective present and the aorist, and this can be easily spelled out as a rule. The question is when we can predict low tone. For the building of the tonal structure of remaining forms, we propose that the stem of the imperative is informative, i.e. a principal part (Finkel and Stump 2007). In this we follow Roberts, but we reach different conclusions.

If a verb has a low tone in the stem used for the imperative form, then it will have low tone in all other forms (pattern I), except when the imperative stem is monosyllabic, in which case the infinitive will have high tone (pattern II). When the verb has high tone in the imperative, things become more complex as conditions get more specific. With many options, one commonly resorts to the existence of a default rule that applies elsewhere. The default for a verb with a high tone in the imperative is to also have high tone for all other forms, i.e. the invariable pattern III grouping verbs $(\mathrm{k}-\mathrm{m})$. In this, it behaves like the default of low tone. Exceptions can be explained by appealing to phonological properties of the stem, but the rules need to be stored somewhere under the control of the morphology. First, if the segmental stem is of the type $/ \mathrm{CVr}-/$ or $/ \mathrm{CVw}-/$ as in (n-o), then the past has low tone, despite all other forms having high tone (pattern IV). If the imperative has the shape $/(\mathrm{H}-) \mathrm{H}+\mathrm{H} /(+$ indicates the mora of the suffix $-i / l)$, then the shape for the infinitive, the imperfective past, and the past will be 
$/(\mathrm{L}-) \mathrm{L}+\mathrm{H} /$ making pattern $\mathrm{VI}$ as in $(\mathrm{r}-\mathrm{u})$. But if the shape is $/ \mathrm{H}-\mathrm{H}+\mathrm{L} /$, for those same forms, the shape will be $/ \mathrm{L}-\mathrm{H}+\mathrm{L} /$ as in $(\mathrm{v}-\mathrm{w})$. Finally, verbs in (p-q) have two segmental stems in alternation (CVV- vs. CVk-); for such verbs with a high tone imperative, the stem for the past tenses always carries low tone (pattern $\mathrm{V}$ ).

This analysis could perhaps be rephrased in a more sophisticated way, but it illustrates a situation where the distribution of tonal changes in paradigms can be accounted for as attending to other aspects of the form without having to appeal to the lexicon.

Having established the rules behind the making of forms in the paradigm, we are left with the second question: what is the function of tone in Kabiyè? Our view is that we are facing a similar type of morphological tone as seen in Tswana. In other words, tone in Kabiyè does not have a morphosyntactic function. Neither low nor high tone is used as an inflectional exponent for any given inflectional category. The fact that high tone is always used for the stem of the imperfective present and the aorist could cause one to ponder whether there is a grammatical connection between high tone and such values. If we were to accept such a view, we would then be confronted with two further issues: (i) what is the grammatical connection between those two tenses which would enable us to make sense, in functional terms, of the fact that the same form (i.e., high tone) encodes both; but most significantly (ii) why do other stems have high tone for other cells of the paradigm?

While morphological tone in Kabiyè and Tswana serves the same purpose, it works in typologically different ways in each language. In Tswana, the rules of high tone assignment apply to all verbs and are aimed at the same cells of the paradigm. ${ }^{10}$ In Kabiyè, however, the assignment of a low tone to a stem can vary from verb to verb and the cells involved also vary. This assignment depends on the application of a complex set of abstract rules linked to properties of the phonological shape of the lexical stem. Verbs which have lexical stems with the identical key property will behave in the same way, otherwise they won't.

\subsection{Morphological tone conditioned by inflectional class}

We have seen two situations where tone has a purely morphological role in the inflection. In the first situation, found in Tswana, it serves as a building block that applies to all verbs and to the same paradigmatic cells. The second situation, found in Kabiyè, is a possible deviation from the first one. Inflectional tone does not involve all verbs, and does not apply to the same cells. A second deviation is found in Acazulco Otomi, where we see that the application of morphological tone is conditioned by inflectional class membership of the verb.

Acazulco Otomi (Oto-Pamean) also has two tones involved in inflection: high (represented with an acute accent) and low (not represented). Hernández Green (2015a, 2015b, forthcoming), proposes that verbs in Acazulco Otomi fall into three main inflectional classes, defined by the specific set of inflectional proclitic markers they select. ${ }^{11}$ Table 5 illustrates the basic paradigms of the three classes. ${ }^{12}$ Class I verbs have two different paradigms depending on whether they are transitive or intransitive. Shading indicates slabs in the paradigm where the lexical tone of the stem is altered, in this case changed to a low tone.

\footnotetext{
${ }^{10}$ When the stem already has an inherent high tone, grammatical high tone is not observable.

${ }^{11}$ There is an additional fourth class including patientive verbs which we will not further discuss here because it is mainly based on class III.

12 Apart from the basic paradigm, Hernández Green $(2015 \mathrm{a}, 2015 \mathrm{~b})$ shows that verbs also have two other paradigms called deictic and of adjunct registration.
} 
Table 5. The three main verbal inflectional classes of Acazulco Otomi.

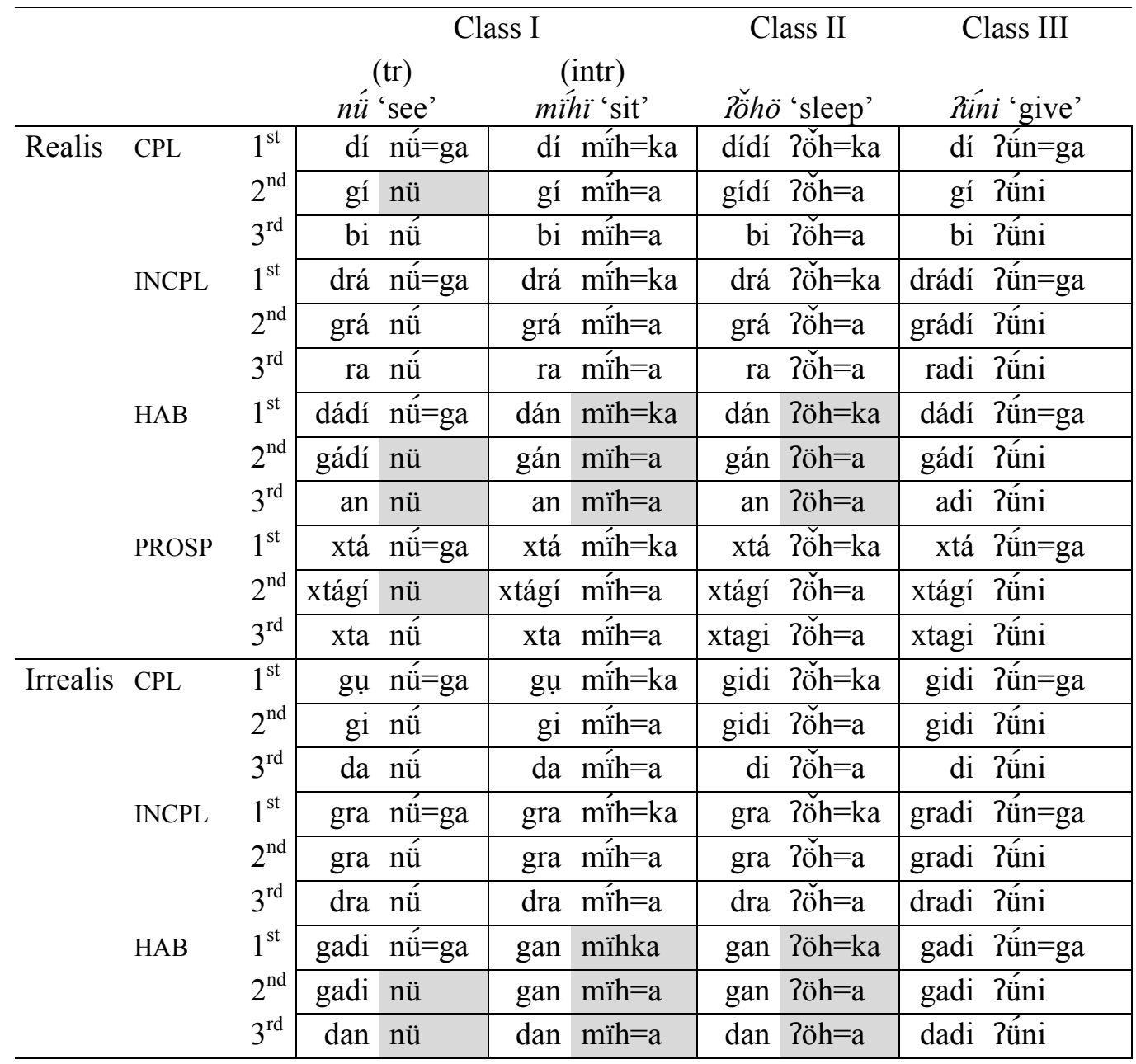

Three things make morphological tone in Acazulco Otomi remarkable typologically:

To begin with, it has an unusual realization. The stem receives a low tone as a default, but it may also receive a high tone under specific circumstances: (i) when the stem is not monosyllabic but consists of a root plus a stem formative (indicated with the + sign) and has no further suffixation; (ii) when the verb is a $\mathrm{V}+\mathrm{N}$ compound; and (iii) when the stem bears the human antipassive suffix -te, the enclitic ='mbé for plural exclusive, the delimative =thoho 'just' or the counterfactual =möhö. These are illustrated in (5) as (a), (b) and (c), respectively.

INCPL.REALIS
a. $r a=z o+n i$ 'S/he's weeping'
b. $r a=t \ddot{u}$-the
'S/he's thirsty' (die-water)
c. $r a=t s a h-t e$
'It's biting (people)'
(e.g. a dog)

$$
\begin{array}{ll}
\text { /L/ > /H/ } & \text { an=zó+ni } \\
\text { /L/ > /H/ } & \text { an=tü-the } \\
\text { /L/ > /H/ } & \text { an=tsáh-te }
\end{array}
$$

HAB.REALIS

'S/he weeps'

'S/he's often thirsty'

'It bites (people)'

(e.g. a dog)

If a verb has a lexical tone which is identical to that of the output of the rules, we cannot observe the effects of morphological tone. 
(6)

INCPL.REALIS
a. $r a=t s a$ 'It's biting it'
$/ \mathrm{L} / \quad>/ \mathrm{L} / \quad \grave{a} n=t s \grave{a}$
'it bites it'
b. $r a=h \dot{t}+x i \quad$ 's/he's whistling'
$/ \mathrm{H} />/ \mathbf{H} / \quad$ an $=h \dot{t}+x i$
's/he whistles'
c. $r a=n u ̈ h-t e \quad$ 's/he's seeing (people)'
$/ \mathrm{H} />/ \mathrm{H} /$
's/he sees (people)'

The distribution of this grammatical tone in Acazulco Otomi is morphological. Like in Kabiyè and Tswana, different cells in the paradigm that have little in common in functional terms require the same tone. However, the conditioning is different. Unlike in Tswana, but like in Kabiyè, morphological tone on Acazulco Otomi is not found in all verbs. But while in Kabiyè, its distribution is linked to the morphophonology, in Acazulco Otomi it is linked to the inflectional class of the verb. This means that it is a property of the paradigm of a certain class of verbs, which in itself is defined by the lexicon. Once speakers know to which inflectional class a given verb belongs, then it is predictable whether that verb will receive morphological tone or not, and if it does, which specific cells will be affected.

\subsection{Morphological tone linked to the lexicon.}

A final type of morphological tone is characterized by a distribution bearing all the typical idiosyncrasies of the lexicon. This is found in Chichimec (Oto-Pamean). As shown in table 6, in Chichimec there are verbs like -pór 'remove' and -?or 'appear' which retain their lexical tone throughout the paradigm. ${ }^{13}$

Table 6. The Chichimec verbs -pór 'remove' and - Por 'appear'

\begin{tabular}{|c|c|c|c|c|c|c|c|c|}
\hline & $1 \mathrm{st}$ & 2nd & $3 \mathrm{SG} / \mathrm{I}$ & 3PL & $1 \mathrm{st}$ & 2nd & $3 \mathrm{SG} /$ & 3PL \\
\hline RS & u-pór & u-pór & u-pór & e-pór & L-H & L-H & L-H & L-H \\
\hline UT & gu-pór & i-pór & ga-pór & a-pór & L-H & L-H & L-H & L-H \\
\hline NT. & tu-pór & su-pór & u-pór & -pór & L-H & L-H & L-H & L-H \\
\hline EC.PST & ku-pór & -pór & u-pór & u-pót & L-H & L-H & L-H & L-H \\
\hline ИМ.Р & u-pór & i-pór & zu-pór & zu-pór & L-H & L-H & L-H & L-H \\
\hline OT & nu-pór & mi-pór & mu-pór & mi-pór & L-H & L-H & L-H & L-H \\
\hline EQ & ra-pór & gi-pór & ru-pór & ru-pór & L-H & L-H & L-H & L-H \\
\hline S & tú-?or & sú-?or & $u$-Por & $e ́-$ - $p o r$ & H-L & H-L & $\mathrm{H}-\mathrm{L}$ & H-L \\
\hline UT & gú-Por & $k i$-Por & gá-?or & gá-?or & H-L & H-L & H-L & H-L \\
\hline NT.PST & tú-Por & sú-Por & ú-?or & $e^{e}-$ Por & H-L & H-L & H-L & H-L \\
\hline REC.PST & $k u^{\prime}$-?or & $k i-P o r$ & kú-Por & $k u^{\prime}$-Por & H-L & H-L & H-L & H-L \\
\hline MM.PST & $\dot{u}$-Por & $i$-Por & $z u^{\prime}-$ ?or & $z \dot{u}-$-Por & H-L & H-L & $\mathrm{H}-\mathrm{L}$ & H-L \\
\hline OT & $n u^{\prime}-$ Por & mi-Por & $m \dot{u}-\mathrm{Por}$ & mi-Por & H-L & $\mathrm{H}-\mathrm{L}$ & H-L & H-L \\
\hline EQ & rá-?or & gi-Por & rú-Por & rú-?or & H-L & H-L & H-L & H-L \\
\hline
\end{tabular}

Table 6 further shows that verbs in Chichimec inflect by means of prefixes for the person of subject (third person has an additional number distinction) and for various TAM values, namely, present, future, anterior past, recent past, immediate past, potential and sequential (a sort of neutral grammatical tense used in the dependent clause in clause combining contexts). These prefixes do not carry lexical tone. In this they are different from the grammatical markers of Tswana or the Otomi clitics in (2). The tone they receive is provided by the word's

\footnotetext{
${ }^{13}$ Chichimec data come from Angulo (1933).
} 
prosodic phonology and it is manifested by inverting the lexical tone of the stem. The inverse happens in Tswana.

However, unlike the verbs in table 6 , most verbs in Chichimec have more than one stem: the majority have only two, while some have up to five. When this happens, the verbs organize these different stems into specific patterns (i.e. the distribution is not entirely chaotic). Following Palancar and Avelino (in preparation) there are at least 14 such patterns. One of those patterns is illustrated by the verbs -tsá 'do' in table 7. As the tone value of affixes appears to be predictable, we shall only be concerned with the stems. To aid visualization of the patterns, each different stem has been assigned a different capital letter and a different type of shading.

Table 7. The stem pattern of the Chichimec verb -tsá 'do'

\begin{tabular}{|c|c|c|c|c|c|c|c|c|c|c|c|c|}
\hline & $1 \mathrm{st}$ & 2nd & $3 \mathrm{SG} / \mathrm{DU}$ & 3PL & $1 \mathrm{st}$ & 2nd & $3 \mathrm{SG} / \mathrm{DU}$ & $3 \mathrm{PL}$ & $1 \mathrm{st}$ & 2nd & $3 \mathrm{SG} / \mathrm{DU}$ & $3 \mathrm{PL}$ \\
\hline PRS & $-t s a ́$ & $-\int a ́$ & -tsá & $-t \int a ́$ & $\mathrm{~A}$ & $\mathrm{D}$ & $\mathrm{A}$ & $\mathrm{B}$ & $\mathrm{H}$ & $\mathrm{H}$ & $\mathrm{H}$ & $\mathrm{H}$ \\
\hline FUT & $-t s \dot{a}$ & $-\int a ́$ & $-t s a ́$ & $-t \int a ́$ & $\mathrm{~A}$ & $\mathrm{D}$ & A & $\mathrm{B}$ & $\mathrm{H}$ & $\mathrm{H}$ & $\mathrm{H}$ & $\mathrm{H}$ \\
\hline ANT.PST & -tsá & $-\int a ́$ & $-t s a ́$ & 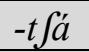 & $\mathrm{A}$ & $\mathrm{D}$ & A & $\mathrm{B}$ & $\mathrm{H}$ & $\mathrm{H}$ & $\mathrm{H}$ & $\mathrm{H}$ \\
\hline REC.PST & -tsá & $-\int a ́$ & $-t s a ́$ & $-t \int a ́$ & $\mathrm{~A}$ & $\mathrm{D}$ & $\mathrm{A}$ & $\mathrm{B}$ & $\mathrm{H}$ & $\mathrm{H}$ & $\mathrm{H}$ & $\mathrm{H}$ \\
\hline IMM.PST & -tsá & $-\int a ́$ & -tsá & $-t \int a ́$ & A & D & A & B & $\mathrm{H}$ & $\mathrm{H}$ & $\mathrm{H}$ & $\mathrm{H}$ \\
\hline РОТ & $-t s a ́$ & $-\int a ́$ & $-t s a ́$ & $-t \int a ́$ & $\mathrm{~A}$ & $\mathrm{D}$ & A & B & $\mathrm{H}$ & $\mathrm{H}$ & $\mathrm{H}$ & $\mathrm{H}$ \\
\hline SEQ & -tsá & $-\int a ́$ & $-t s a ́$ & $-t \int a ́$ & $\mathrm{~A}$ & $\mathrm{D}$ & A & $\mathrm{B}$ & $\mathrm{H}$ & $\mathrm{H}$ & $\mathrm{H}$ & $\mathrm{H}$ \\
\hline
\end{tabular}

The verb -tsá 'do' requires three stems, annotated here for convenience as 'A', 'B' and ' $\mathrm{D}$ '. The A-stem could be taken as a lexical default, while the B-stem and the D-stem are used for a specific person value, e.g. the D-stem is used for the second person. Now take the verb -sá 'win' in table 8. This verb lacks a segmentally different D-stem, but we observe a contrast in tone for the same cells in which we have the D-stem of -tsá 'do'.

Table 8. The stem pattern of the Chichimec verb -sá 'win'

\begin{tabular}{|c|c|c|c|c|c|c|c|c|c|c|c|c|}
\hline & $1 \mathrm{st}$ & 2nd & $3 \mathrm{SG} / \mathrm{DU}$ & $3 \mathrm{PL}$ & $1 \mathrm{st}$ & 2nd & $3 \mathrm{SG} / \mathrm{DU}$ & $3 \mathrm{PL}$ & $1 \mathrm{st}$ & 2nd & $3 \mathrm{SG} / \mathrm{DU}$ & $3 \mathrm{PL}$ \\
\hline PRS & $-s a ́$ & $-s a$ & $-s a ́$ & $-t \int a ́$ & A & A & $\mathrm{A}$ & $\mathrm{B}$ & $\mathrm{H}$ & $\mathrm{L}$ & $\mathrm{H}$ & $\mathrm{H}$ \\
\hline FUT & $-s a ́$ & $-s a$ & $-s a ́$ & $-t \int a ́$ & $\mathrm{~A}$ & $\mathrm{~A}$ & $\mathrm{~A}$ & $\mathrm{~B}$ & $\mathrm{H}$ & $\mathrm{L}$ & $\mathrm{H}$ & $\mathrm{H}$ \\
\hline ANT.PST & $-s a ́$ & $-s a$ & $-s \dot{a}$ & $-t \int a ́$ & $\mathrm{~A}$ & $\mathrm{~A}$ & $\mathrm{~A}$ & $\mathrm{~B}$ & $\mathrm{H}$ & $\mathrm{L}$ & $\mathrm{H}$ & $\mathrm{H}$ \\
\hline REC.PST & $-s a ́$ & $-s a$ & $-s a ́$ & $-t \int a ́$ & A & A & A & B & $\mathrm{H}$ & $\mathrm{L}$ & $\mathrm{H}$ & $\mathrm{H}$ \\
\hline IMM.PST & -sá & $-s a$ & $-s \dot{a}$ & $-t \int_{a}^{\prime}$ & $\mathrm{A}$ & $\mathrm{A}$ & $\mathrm{A}$ & $\mathrm{B}$ & $\mathrm{H}$ & $\mathrm{L}$ & $\mathrm{H}$ & $\mathrm{H}$ \\
\hline POT & $-s a ́$ & $-s a$ & $-s \dot{a}$ & $-t \int a ́$ & A & A & A & B & $\mathrm{H}$ & $\mathrm{L}$ & $\mathrm{H}$ & $\mathrm{H}$ \\
\hline SEQ & $-s a ́$ & $-s a$ & $-s a ́$ & $-t \int_{a}^{\prime}$ & A & A & A & B & $\mathrm{H}$ & $\mathrm{L}$ & $\mathrm{H}$ & $\mathrm{H}$ \\
\hline
\end{tabular}

For such a case, one could in principle posit that the verb -sá 'win' follows the same stem alternation pattern as -tsá 'do', and that the low tone is just a phonological property of the D-stem of -sá to distinguish it from its A-stem (i.e., the stems would otherwise be segmentally homophonous). If this view is correct, tone would bear no inflectional function here; instead being a lexical property of stems. Similarly, if we pursue this analysis, we would have to conclude that the D-stem of the verb -tsá 'do' just happens to have the same lexical tone as the A-stem.

A more complex pattern of stem alternations is given in table 9. Here things start getting more interesting since we observe a high tone in the potential form of the verbs - $R i$ 'want' and -hun 'throw'. 
Table 9. The stem pattern of the Chichimec verbs - $P a$ 'bury', $-? i$ 'want' and -hun 'throw'

\begin{tabular}{|c|c|c|c|c|c|c|c|c|c|c|c|c|}
\hline & $1 \mathrm{st}$ & 2nd & $3 \mathrm{SG} / \mathrm{DU}$ & 3PL & $1 \mathrm{st}$ & 2nd & $3 \mathrm{SG} / \mathrm{DU}$ & 3PL & $1 \mathrm{st}$ & 2nd & $3 \mathrm{SG} / \mathrm{DU}$ & $3 \mathrm{PL}$ \\
\hline PRS & $-2 a$ & $-? a$ & $-2 a$ & $-r ? a$ & $\mathrm{~A}$ & $\mathrm{~A}$ & $\mathrm{~A}$ & B & $\mathrm{L}$ & $\mathrm{L}$ & $\mathrm{L}$ & $\mathrm{L}$ \\
\hline FUT & $-2 a$ & $-t a$ & $-n d a$ & $-r ? a$ & $\mathrm{~A}$ & $\mathrm{D}$ & $\mathrm{C}$ & B & $\mathrm{L}$ & $\mathrm{L}$ & $\mathrm{L}$ & $\mathrm{L}$ \\
\hline ANT.PST & $-2 a$ & $-t a$ & $-n d a$ & $-r P a$ & $\mathrm{~A}$ & $\mathrm{D}$ & $\mathrm{C}$ & $\mathrm{B}$ & $\mathrm{L}$ & $\mathrm{L}$ & $\mathrm{L}$ & $\mathrm{L}$ \\
\hline REC.PST & $-2 a$ & $-t a$ & $-n d a$ & $-r ? a$ & $\mathrm{~A}$ & $\mathrm{D}$ & $\mathrm{C}$ & $\mathrm{B}$ & $\mathrm{L}$ & $\mathrm{L}$ & $\mathrm{L}$ & $\mathrm{L}$ \\
\hline IMM.PST & $-P a$ & $-t a$ & $-2 a$ & $-r P a$ & $\mathrm{~A}$ & $\mathrm{D}$ & A & B & $\mathrm{L}$ & $\mathrm{L}$ & $\mathrm{L}$ & $\mathrm{L}$ \\
\hline РОТ & $-? a$ & $-t a$ & $-2 a$ & $-r ? a$ & $\mathrm{~A}$ & $\mathrm{D}$ & A & B & $\mathrm{L}$ & $\mathrm{L}$ & $\mathrm{L}$ & $\mathrm{L}$ \\
\hline SEQ & $-2 a$ & $-t a$ & $-2 a$ & $-r ? a$ & $\mathrm{~A}$ & $\mathrm{D}$ & $\mathrm{A}$ & B & $\mathrm{L}$ & $\mathrm{L}$ & $\mathrm{L}$ & $\mathrm{L}$ \\
\hline PRS & $-? i$ & $-P i$ & $-? i$ & $-r \Re$ & $\mathrm{A}$ & A & A & $\mathrm{B}$ & $\mathrm{L}$ & $\mathrm{L}$ & $\mathrm{L}$ & $\mathrm{H}$ \\
\hline FUT & $-\Re i$ & $-t i$ & $-n d i$ & $-r \bigcap^{\prime}$ & $\mathrm{A}$ & $\bar{D}$ & $\mathrm{C}$ & B & $\mathrm{L}$ & $\mathrm{H}$ & $\mathrm{H}$ & $\mathrm{H}$ \\
\hline ANT.PST & $-? i$ & $-t i^{\prime}$ & -ndí & $-r \Re$ & $\mathrm{A}$ & $\mathrm{D}$ & $\mathrm{C}$ & $\mathrm{B}$ & $\mathrm{L}$ & $\mathrm{H}$ & $\mathrm{H}$ & $\mathrm{H}$ \\
\hline REC.PST & $-? i$ & $-t i^{\prime}$ & $-n d i$ & $-r \Re$ & $\mathrm{A}$ & $\mathrm{D}$ & $\mathrm{C}$ & B & $\mathrm{L}$ & $\mathrm{H}$ & $\mathrm{H}$ & $\mathrm{H}$ \\
\hline IMM.PST & $-? i$ & $-t i ́$ & $-? i$ & $-r \Re$ & $\mathrm{A}$ & $\bar{D}$ & $\mathrm{~A}$ & B & $\mathrm{L}$ & $\mathrm{H}$ & $\mathrm{L}$ & $\mathrm{H}$ \\
\hline РОТ & $-h^{\prime}$ & $-t i$ & $-\bigcap^{\prime}$ & $-r ?$ & $\mathrm{~A}$ & D & A & B & $\mathrm{H}$ & $\mathrm{H}$ & $\mathrm{H}$ & $\mathrm{H}$ \\
\hline SEQ & $-i i$ & $-t i^{\prime}$ & $-i i$ & $-r \Re$ & $\mathrm{A}$ & $\mathrm{D}$ & $\mathrm{A}$ & B & $\mathrm{L}$ & $\mathrm{H}$ & $\mathrm{H}$ & $\mathrm{H}$ \\
\hline PRS & -hun & $-h u n$ & $-h u n$ & -hún & $\mathrm{A}$ & A & $\mathrm{A}$ & $\mathrm{B}$ ? & $\mathrm{L}$ & $\mathrm{L}$ & $\mathrm{L}$ & $\mathrm{H}$ \\
\hline FUT & -hun & -nhin & $-n h i n$ & -hún & $\mathrm{A}$ & $\mathrm{D}$ & $\mathrm{C}$ & $\mathrm{B}$ ? & $\mathrm{L}$ & $\mathrm{H}$ & $\mathrm{L}$ & $\mathrm{H}$ \\
\hline ANT.PST & - hun & -nhín & $-n h i n$ & -hún & A & $\mathrm{D}$ & $\mathrm{C}$ & B? & $\mathrm{L}$ & $\mathrm{H}$ & $\mathrm{L}$ & $\mathrm{H}$ \\
\hline REC.PST & -hun & -nhín & $-n h i n$ & -hún & A & $\mathrm{D}$ & $\mathrm{C}$ & $\mathrm{B}$ ? & $\mathrm{L}$ & $\mathrm{H}$ & $\mathrm{L}$ & $\mathrm{H}$ \\
\hline IMM.PST & -hun & -nhín & $-h u n$ & -hún & $\mathrm{A}$ & $\mathrm{D}$ & $\mathrm{A}$ & B? & $\mathrm{L}$ & $\mathrm{H}$ & $\mathrm{L}$ & $\mathrm{H}$ \\
\hline POT & -hún & -nhín & -hún & -hún & $\mathrm{A}$ & $\mathrm{D}$ & A & $\mathrm{B}$ ? & $\mathrm{H}$ & $\mathrm{H}$ & $\mathrm{H}$ & $\mathrm{H}$ \\
\hline SEQ & -hun & -nhín & -hun & -hún & $\mathrm{A}$ & $\mathrm{D}$ & $\mathrm{A}$ & B? & $\mathrm{L}$ & $\mathrm{H}$ & $\mathrm{L}$ & $\mathrm{H}$ \\
\hline
\end{tabular}

Verbs like - $? i$ 'want' and -hun 'throw' could be said to have the same pattern as - $P a$ 'bury', only that their B-stem and D-stem would have a high tone. ${ }^{14}$ But the high tone in the A-stem of the verbs $-? i$ and $-h u n$ for the potential of the first person and the third person singular and dual is surprising. One does not expect a different tone here because at the segmental level there is no comparable stem change in other verbs for the same cells. We could take this to be an incipient inflectional use of tone, in this case to mark the potential mood, but its further idiosyncrasies would perhaps let us down.

For example, in other verbs, instead of a high tone we find a low tone, like in the verb -mé 'defend' in table 10. As the A-stem has a high tone, one could think of a mechanism of tonal inversion. Notice that a low tone also applies to the second person, suggesting that we are facing a verb with a stem pattern somehow similar to that of table 8 , but with a D-stem like in table 9 .

\footnotetext{
${ }^{14}$ We could assume that the B-stem of -hun 'throw' in built by a tone contrast like the D-stem of -sá 'win' in table 8 .
} 
Table 10. The stem pattern of the Chichimec verb -mé 'defend'

\begin{tabular}{|c|c|c|c|c|c|c|c|c|c|c|c|c|}
\hline & $1 \mathrm{st}$ & 2nd & $3 \mathrm{SG} / \mathrm{DU}$ & $3 \mathrm{PL}$ & $1 \mathrm{st}$ & 2nd & $3 \mathrm{SG} / \mathrm{DU}$ & $3 \mathrm{PL}$ & $1 \mathrm{st}$ & 2nd & $3 \mathrm{SG} / \mathrm{DU}$ & $3 \mathrm{PL}$ \\
\hline PRS & $-m e ́$ & $-m e ́$ & $-m e ́$ & -mhé & $\mathrm{A}$ & A & A & $\mathrm{B}$ & $\mathrm{H}$ & $\mathrm{H}$ & $\mathrm{H}$ & $\mathrm{H}$ \\
\hline FUT & $-m e ́$ & $-m e$ & $-m e ̨$ & -mhę & A & $\mathrm{D} ?$ & A & B & $\mathrm{H}$ & $\mathrm{L}$ & $\mathrm{H}$ & $\mathrm{H}$ \\
\hline ANT.PST & $-m e ́$ & $-m e ̨$ & -mé & -mhę & A & $\mathrm{D} ?$ & A & $\mathrm{B}$ & $\mathrm{H}$ & $\mathrm{L}$ & $\mathrm{H}$ & $\mathrm{H}$ \\
\hline REC.PST & $-m e$ & $-m e$ & $-m e ̨$ & -mhę & A & $\mathrm{D} ?$ & A & B & $\mathrm{H}$ & $\mathrm{L}$ & $\mathrm{H}$ & $\mathrm{H}$ \\
\hline IMM.PST & $-m e ́$ & $-m e ́$ & $-m e ́$ & -mhé & $\mathrm{A}$ & $\mathrm{D} ?$ & A & $\mathrm{B}$ & $\mathrm{H}$ & $\mathrm{L}$ & $\mathrm{H}$ & $\mathrm{H}$ \\
\hline POT & $-m e$ & $-m e$ & $-m e$ & -mhę & A & $\mathrm{D} ?$ & A & B & $\mathrm{L}$ & L & L & $\mathrm{H}$ \\
\hline SEQ & $-m e ̨$ & $-m e ̨$ & $-m e$ & $-m h e ̨$ & A & $\mathrm{D} ?$ & A & B & $\mathrm{H}$ & $\mathrm{L}$ & $\mathrm{H}$ & $\mathrm{H}$ \\
\hline
\end{tabular}

To complicate things further, the verb -tsá 'hurt' in table 11 shows yet another pattern. Here the potential is encoded throughout all persons by a low tone. ${ }^{15}$ But most importantly, this pattern is not exclusive to the potential as it also applies to the forms of the present and the recent past.

Table 11. The stem pattern of the Chichimec verb -tsa 'hurt'

\begin{tabular}{|c|c|c|c|c|c|c|c|c|c|c|c|c|}
\hline & $1 \mathrm{st}$ & 2nd & $3 \mathrm{SG} / \mathrm{DU}$ & $3 \mathrm{PL}$ & $1 \mathrm{st}$ & $2 \mathrm{nd}$ & $3 \mathrm{SG} / \mathrm{DU}$ & $3 \mathrm{PL}$ & $1 \mathrm{st}$ & 2nd & $3 \mathrm{SG} / \mathrm{DU}$ & $3 \mathrm{PL}$ \\
\hline PRS & $-t s a$ & $-\int a$ & $-t s a$ & $-t \int a$ & $\mathrm{~A}$ & $\mathrm{D}$ & A & $\mathrm{B}$ & $\mathrm{L}$ & L & L & L \\
\hline FUT & $-t s a ́$ & $-\int a$ & $-z a$ & $-t \int a$ & A & $\mathrm{D}$ & $\mathrm{C}$ & B & $\mathrm{H}$ & $\mathrm{L}$ & $\mathrm{H}$ & $\mathrm{H}$ \\
\hline ANT.PST & $-t s a ́$ & $-\int a$ & $-z \dot{a}$ & $-t \int a$ & A & $\mathrm{D}$ & $\mathrm{C}$ & $\mathrm{B}$ & $\mathrm{H}$ & $\mathrm{L}$ & $\mathrm{H}$ & $\mathrm{H}$ \\
\hline REC.PST & $-t s a$ & $-\int a$ & $-z a$ & $-t \int a$ & A & $\mathrm{D}$ & $\mathrm{C}$ & B & $\mathrm{L}$ & L & L & L \\
\hline IMM.PST & -tsá & $-\int a$ & -tsá & $-t \int a$ & A & D & A & B & $\mathrm{H}$ & $\mathrm{L}$ & $\mathrm{H}$ & $\mathrm{H}$ \\
\hline POT & $-t s a$ & $-\int a$ & $-t s a$ & $-t \int a$ & A & $\mathrm{D}$ & A & B & $\mathrm{L}$ & L & L & L \\
\hline SEQ & -tsá & $-\int a$ & -tsá & $-t \int a$ & $\mathrm{~A}$ & $\mathrm{D}$ & A & B & $\mathrm{H}$ & $\mathrm{L}$ & $\mathrm{H}$ & $\mathrm{H}$ \\
\hline
\end{tabular}

The tonal patterns increase in numbers as we go from one verb to the next. Our understanding of Chichimec verbs is based on the behavior of only 168 verbs from Angulo (1933) and thus remains limited. Of these, only 31 display some sort of tonal perturbations, but only a handful are of the sort described for the verbs in tables 9-11. This suggests that morphological tone in Chichimec remains tightly and intricately linked to the lexicon. The Chichimec case reminds us of the stem tonal stem patterns in Khaling whose distribution Jacques (this volume) accounts for appealing to the rules of a historical sound change. However, for Chichimec the key to the system appears to have been lost. This means that there is no indication from the morphophonology or the morphology as to what verbs have morphological tone and which do not. Similarly, once we know that a given verb has tone perturbations, we are not in a position to predict in what cells this will happen. Speakers need to store this information as part of the lexical entry.

In the following sections, I present a final type of inflectional tone which is different from all others presented so far. In this type, there is a great degree of tonal allomorphy in the realization of morphosyntactic values. The optimal way to account for this type of allomorphy is by means of inflectional classes defined by tone. To show this type, let us start with Tlatepuzco Chinantec, another Oto-Manguean language.

\footnotetext{
${ }^{15}$ Whether the verbs - $i i$ 'want' and -hun 'throw' in table 9 have the potential encoded in the same way as -mé 'defend' is unclear when it comes to the cells for the second person and for the third person singular and dual.
} 


\section{Tonal classes: Inflectional classes made by tone.}

Tlatepuzco Chinantec has six tones involved in lexical contrasts (cf. Mandarin Chinese has only four): three level tones and two rising contours (low-mid /12/ and low-high /13/). Out of these six tones, five are involved in verbal inflection in rather intricate ways. Verbs in Chinantec inflect for TAM by means of prefixes (including zero suffixes or bare stems). These prefixes, in turn, are associated with stems inflected for aspect/mood by tone, e.g. the past prefix $c a^{l}$ - and the hodiernal past prefix $n a^{2}$ - are always affixed to the completive stem. The same tonally inflected stems also indicate distinctions involving the person of the subject. The relevant person values for the inflection are first person singular and dual, second person and third person (see for example Merrifield 1968, Pace 1990, Foris 2000, etc.).

The sources propose that the paradigm of a verb can be reconstructed from three principal stems: the completive, the incompletive and the irrealis stem. In table 12 , we obeserve the inflected stems of six different verbs (a-f). ${ }^{16}$

Table 12. The twelve inflected stems of six verbs in Tlatepuzco Chinantec.

\begin{tabular}{|c|c|c|c|c|c|c|c|c|c|c|}
\hline \multirow{7}{*}{ CPL.STEM } & & \multirow{7}{*}{$\begin{array}{l}\text { 'bend' } \\
\text { 'gnaw' } \\
\text { 'bring' } \\
\text { 'call' } \\
\text { 'cut' } \\
\text { 'scare' }\end{array}$} & \multicolumn{2}{|c|}{$1 \mathrm{SG}$} & \multicolumn{2}{|l|}{$1 \mathrm{PL}$} & \multicolumn{2}{|l|}{2} & \multicolumn{2}{|l|}{3} \\
\hline & & & hú ${ }^{1}$ & 1 & hú? ${ }^{13}$ & 13 & hú? ${ }^{1}$ & 1 & hú? ${ }^{2}$ & 2 \\
\hline & & & tsǿ́ ${ }^{1}$ & 1 & tsǿ? ${ }^{13}$ & 13 & tsǿ? ${ }^{1}$ & 1 & tsǿ? ${ }^{1}$ & 1 \\
\hline & & & quián $^{1}$ & 1 & quián ${ }^{13}$ & 13 & quián ${ }^{12}$ & 12 & quián ${ }^{2}$ & 2 \\
\hline & & & tǿ? ${ }^{1}$ & 1 & tǿ? ${ }^{13}$ & 13 & tǿ? ${ }^{12}$ & 12 & tǿ? ${ }^{1}$ & 1 \\
\hline & & & $\operatorname{tiu}^{1}$ & 1 & tiu $^{3}$ & 3 & $\mathrm{tiu}^{32}$ & 32 & tiu $^{1}$ & 1 \\
\hline & & & Pán ${ }^{2}$ & 2 & Pán ${ }^{13}$ & 13 & Pán ${ }^{1}$ & 1 & Pán² & 2 \\
\hline \multirow[t]{6}{*}{ INCPL.STEM } & \multirow{6}{*}{$\begin{array}{l}\text { a. } \\
\text { b. } \\
\text { c. } \\
\text { d. } \\
\text { e. } \\
\text { f. }\end{array}$} & \multirow{6}{*}{$\begin{array}{l}\text { 'bend' } \\
\text { 'gnaw' } \\
\text { 'bring' } \\
\text { 'call' } \\
\text { 'cut' } \\
\text { 'scare' }\end{array}$} & hú? $?^{12}$ & 12 & hú? $?^{12}$ & 12 & hú? $2^{12}$ & 12 & hú? ${ }^{2}$ & 2 \\
\hline & & & tsǿ? ${ }^{12}$ & 12 & tsǿ́? $^{12}$ & 12 & tsǿ? ${ }^{12}$ & 12 & tsǿ? ${ }^{12}$ & 12 \\
\hline & & & quián ${ }^{12}$ & 12 & quián ${ }^{12}$ & 12 & quián ${ }^{12}$ & 12 & quián ${ }^{2}$ & 2 \\
\hline & & & tǿ́ $2^{12}$ & 12 & tǿर ${ }^{12}$ & 12 & tǿ? ${ }^{12}$ & 12 & tǿर ${ }^{2}$ & 2 \\
\hline & & & tiu $^{12}$ & 12 & tiu $^{2}$ & 2 & tiu $^{2}$ & 2 & tiu $^{12}$ & 12 \\
\hline & & & Pán ${ }^{2}$ & 2 & Pán ${ }^{12}$ & 12 & Pán & 2 & Pán² & 2 \\
\hline \multirow[t]{6}{*}{ IRR.STEM } & \multirow{6}{*}{$\begin{array}{l}\text { a. } \\
\text { b. } \\
\text { c. } \\
\text { d. } \\
\text { e. } \\
\text { f. }\end{array}$} & \multirow{6}{*}{$\begin{array}{l}\text { 'bend' } \\
\text { 'gnaw' } \\
\text { 'bring' } \\
\text { 'call' } \\
\text { 'cut' } \\
\text { 'scare' }\end{array}$} & hú? $1^{13}$ & 13 & hú? ${ }^{13}$ & 13 & hú? $2^{13}$ & 13 & hú? ${ }^{2}$ & 2 \\
\hline & & & tsǿ: ${ }^{13}$ & 13 & tsǿ́ $P^{13}$ & 13 & tsǿ: ${ }^{13}$ & 13 & tsó́ ${ }^{1}$ & 1 \\
\hline & & & quián & 13 & quián ${ }^{13}$ & 13 & quián ${ }^{13}$ & 13 & quián ${ }^{2}$ & 2 \\
\hline & & & tǿ' ${ }^{13}$ & 13 & tǿर ${ }^{13}$ & 13 & tǿ? ${ }^{13}$ & 13 & tǿर ${ }^{2}$ & 2 \\
\hline & & & tiu $^{13}$ & 13 & tiu $^{3}$ & 3 & tiú $^{3}$ & 3 & tiu $^{1}$ & 1 \\
\hline & & & Pán ${ }^{3}$ & 3 & Pán ${ }^{13}$ & 13 & ?án ${ }^{3}$ & 3 & Pán ${ }^{2}$ & 2 \\
\hline
\end{tabular}

A glance at the distribution of tones in the inflected forms in table 12 suffices to show that tone in Tlatepuzco Chinantec verbal inflection does not work in the same predictable ways as it does in languages like Yoloxóchitl Mixtec in $\S 3$. In Chinantec there is no evident consistent mapping between form and meaning. For example, for the encoding of the first person singular (the first column in table 12 ), one could say that tone values $/ 1 /, / 12$ / and $/ 13$ / encode the bundles $\{1 \mathrm{SG}, \mathrm{CPL}\},\{1 \mathrm{SG}, \mathrm{INCPL}\}$ and $\{1 \mathrm{SG}, \mathrm{IRR}\}$, respectively. While this would already have to exclude the pattern in the verb in (f), to complete this picture one would also have to

${ }^{16}$ The data of Tlatepuzco Chinantec come from Merrifield and Anderson (2007). 
account for the many other instances where exactly the same tone values are found in other cells of the paradigm to encode other, very different grammatical information, as indicated by the shading. This suggests that the distribution of tone values is, if anything, morphological.

This type of tonal inflection provides further challenges for a theory of tone, because contrary to morphosyntactic tone, identifying a form of a verb in Chinantec that may serve as a lexical base from which the tone values of other forms can be derived is, in our humble opinion, a futile task (for a similar position, but stated differently, see Finkel and Stump, 2009). However, qui quaerit invenit... and Baerman and Palancar (2014) propose that there is still some structure beyond the apparent chaos.

In this regard, Baerman and Palancar (2014) propose that one way to start finding some paradigmatic structure can be accomplished by first isolating third person forms from other person forms. If we then concentrate on the forms involving other persons, we start to see some patterns emerging. For example, one possible analysis of the data in table 12 is that the verbs in (a-d) follow the same pattern: incompletive is marked by /12/ and irrealis by /13/ without person distinctions. But the verbs then fall into two inflectional classes attending to how they mark the completive, all encode first person singular and plural by $/ 1 /$ and $/ 13 /$, respectively, whereas for the second person, verbs in (a-b) use /1/ while the verbs in (c-d) use $/ 2 /$. Verbs in (e) and (f) would have to be accounted for as being deviant or irregular. All such verbs would then have to be further analyzed as belonging to other independent classes attending to the ways they encode the third person. In reality, things become more complex when we move from a handful of verbs to hundreds of them. As a result of this, a typical Chinantecan language is often analyzed as consisting of 70 or more such classes (see Palancar 2014).

A very similar system to Chinantec is found in Yaitepec Chatino, an Eastern Chatino language of the Zapotecan branch with ten contrastive tones. ${ }^{17}$ Verbs in Yaitepec Chatino inflect for four aspect-mood values: completive, potential, habitual and progressive (also called 'continuous' or 'continuative'). Verbs have different stems for each value, and tone plays a major role in the marking of aspect-mood distinctions as well as distinctions of person of subject. Examples of three different paradigms are given in table 13.

Table 13. The Yaitepec Chatino verbs $x n u$ 'leave behind', swi 'choose' and jwi 'kill'

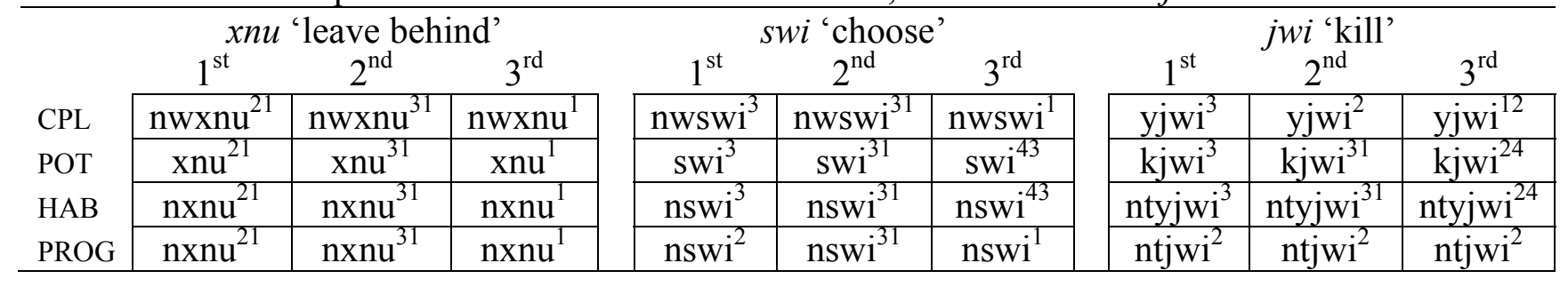

The verb $x n u$ 'leave behind' has contrastive tone for person, but not for aspect-mood. The verb swi 'choose' has invariant tone for the second person. The forms for potential and habitual receive the same tone; a pattern followed by many verbs, but not all. The verb jwi 'kill' is similar to $s w i$ 'choose' in many respects, but we have different tones involved in the marking of second person. The dataset in Rasch (2015) includes 324 inflected verbs and they could be said to instantiate almost 90 different tonal paradigms. A handful of such paradigms have an alternative tone in one or more cells, for example the transitive verb $x k w i$ 'boil'

\footnotetext{
${ }^{17}$ According to Rasch (2015), there are three level tones: /1/ High with a slight rising; /2/ High, but slightly lower than /1/; /3/ Mid; and seven contours: /31/ Mid-rising; /21/ High-rising, rising more recognizably than /1/; /14/ High and sharply falling, starting at /1/ and continuing to fall; /12/ and /23/ High and falling; /24/ High and sharply falling; and /43/ Low and rising.
} 
inflects like $x n u$ 'leave behind', but as it can also have a tone / 31 / for first person completive, it is treated as belonging to a different class. If we discard such cases, and a handful of inanimate verbs that cannot be inflected in all persons for semantic reasons, we are left with the 75 paradigms given in table 14 in the Appendix. ${ }^{18}$

All ten lexical tones are also found at least once in the 75 different paradigms. A correlation of tone value and person is given in table 15 (no relevant correlations are found involving aspect-mood). The figures indicate the number of times a given tone is found in a given cell across the paradigms of the classes.

Table 15. Tone values used in the tonal classes of Yaitepec Chatino per person value.

\begin{tabular}{|c|c|c|c|c|c|c|c|c|}
\hline Tones & $1 \mathrm{st}$ & 2nd & $3 \mathrm{rd}$ & Total & $1 \mathrm{st}$ & 2nd & 3rd & Total \\
\hline$/ 1 /$ & 19 & 47 & 25 & 91 & $21 \%$ & $52 \%$ & $27 \%$ & $100 \%$ \\
\hline$/ 2 /$ & 28 & 48 & 10 & 86 & $32 \%$ & $57 \%$ & $11 \%$ & $100 \%$ \\
\hline$/ 3 /$ & 29 & 0 & 35 & 64 & $45 \%$ & $0 \%$ & $55 \%$ & $100 \%$ \\
\hline$/ 12 /$ & 22 & 0 & 38 & 60 & $36 \%$ & $0 \%$ & $64 \%$ & $100 \%$ \\
\hline$/ 14 /$ & 0 & 0 & 3 & 3 & $0 \%$ & $0 \%$ & $100 \%$ & $100 \%$ \\
\hline$/ 21 /$ & 41 & 0 & 24 & 65 & $63 \%$ & $0 \%$ & $37 \%$ & $100 \%$ \\
\hline$/ 23 /$ & 5 & 0 & 15 & 20 & $25 \%$ & $0 \%$ & $75 \%$ & $100 \%$ \\
\hline /24/ & 0 & 0 & 55 & 55 & $0 \%$ & $0 \%$ & $100 \%$ & $100 \%$ \\
\hline$/ 31 /$ & 7 & 130 & 14 & 151 & $4 \%$ & $87 \%$ & $9 \%$ & $100 \%$ \\
\hline /43/ & 74 & 0 & 6 & 80 & $93 \%$ & $0 \%$ & $7 \%$ & $100 \%$ \\
\hline
\end{tabular}

Yaitepec Chatino is a mixed system regarding the mapping of a specific form to a specific morphosyntactic value. There are, for example, tones which are associated with a specific person: tone $/ 24 /$ only occurs in third person forms; tone $/ 43$ / could be treated as an exponent of first person; and we could practically say the same about tone $/ 31 /$ but for second person. Other tones are used for more than one person so a clear mapping between form and meaning breaks down here. Also, while all ten tones are found in third person forms and most of them in first person forms, only three of them are used to encode second person. This suggests that the marking of second person attends to other sorts of rules. We can explore this possibility further.

For example, in complex systems like Yaitepec Chatino, it often happens that tone assignment for a specific value may be more predictable for some areas of the paradigm than for other areas. This is the view taken by implicative approaches to inflectional morphology in works such as Bonami and Boyé (2007), Montermini and Bonami (2013), and Bonami and Luís (2014), which are inspired by Morin (1987). Such works explore the degree of predictability that exists among the cells of a given paradigm. As for Yaitepec Chatino, it is possible to find instances where the tone of the second person can be predicted from the marking of the third person (the same cannot be said of the marking for the first person, which

\footnotetext{
${ }^{18}$ The most complex tonal system in Oto-Manguean, and possibly in the world's languages, is found in Tlapanec (Tlapanecan). In his grammar of the Tlapanec language of Malinaltepec, Suárez (1983) provides information about the tones in the inflectional paradigms of about 160 verbs. Out of these, 135 fall into at least 18 different tonal classes, but 24 of them have more complex tonal paradigms. Such verbs are the type of transitive verbs that express actions that may involve two persons in an actor-undergoer sort of relation (e.g., $1>2,1 \mathrm{pl}>2,2>3$, etc.). Each of these types of interrelation constitutes a cell in the paradigm of these verbs. There are 30 cells in total and tone plays a fundamental role in the making of such paradigms. These 24 verbs, which were selected at random by Suárez to register tone, already display 20 different tonal classes!
} 
is far more chaotic, i.e. unpredictable). This is shown in table 16 , where we compare the correlations between the tone used for the $\{3, \mathrm{CPL}\}$ with the one used for the $\{2, \mathrm{CPL}\}$.

Table 16. Tone correlations between 3.CPL and 2.CPL in Yaitepec Chatino

\begin{tabular}{|c|c|c|c|c|c|c|c|}
\hline$\{3, \mathrm{CPL}\}$ & \multicolumn{4}{|c|}{$2, \mathrm{CPL}$} & \multicolumn{3}{|c|}{$2, \mathrm{CPL}$} \\
\hline Tones & $/ 1 /$ & $12 /$ & /31/ & \multirow{10}{*}{$\begin{array}{l}17 \\
8 \\
2 \\
1 \\
1 \\
10 \\
9 \\
22 \\
5\end{array}$} & $/ 1 /$ & $/ 2 /$ & /31/ \\
\hline /1/ & 0 & 0 & 17 & & - & - & $100 \%$ \\
\hline$/ 3 /$ & 0 & 0 & 8 & & - & - & $100 \%$ \\
\hline /21/ & 0 & 0 & 2 & & - & - & $100 \%$ \\
\hline /24/ & 0 & 0 & 1 & & - & - & $100 \%$ \\
\hline /14/ & 0 & 0 & 1 & & - & - & $100 \%$ \\
\hline$/ 31 /$ & 10 & 0 & 0 & & $100 \%$ & - & - \\
\hline /23/ & 8 & 1 & 0 & & $88 \%$ & $12 \%$ & - \\
\hline /12/ & 3 & 18 & 1 & & $14 \%$ & $82 \%$ & $4 \%$ \\
\hline$/ 2 /$ & 0 & 3 & 2 & & - & $60 \%$ & $40 \%$ \\
\hline
\end{tabular}

At least six tones $(1,3,21,24,14$ and 31$)$ when found in the third person completive render a predictability value of $100 \%$ with regard to the tone value we will find in the second person completive. This actually happens regardless of aspect-mood, because the same correlation is found in the potential and the progressive (although not shown in the table). But beyond those tones, certainty of outcomes cannot be guaranteed. The next best correlation is $/ 23 /$, which will most likely render $/ 1 /$ for second person, followed by $/ 12 /$, etc. This suggests that for a substantial part of the 75 patterns, the assignment of tone to the second person is subject to a morphophonological operation. But in situations like this, when some tone value is predictable from another tone value, one still needs to appeal to the morphology, because the specific tone value we are to find for the second person is not in itself given by the phonology. In other words, there is nothing inherently phonological that would make a tone $/ 31 /$ become /1/ or vice versa. Yaitepec Chatino evolved from an ancestor system which might have been very similar to conservative Zenzontepec Chatino as described in Campbell (this volume) where the tonal marking for second person is to a large extent still predictable.

Whether speakers of Chinantec or Yaitepec Chatino learn their paradigms in the way we analyze them or whether they learn them on a cell-to-cell basis as if each form were an independent word remains an open question, which we must leave to the experts of child language acquisition. For the moment, the structure in inflectional classes appears to be the most convenient way to deal with such systems.

\section{Final remarks}

I have outlined here a typology of the different situations where tone is involved in inflection taking a morphological perspective. I have illustrated most of the types using Oto-Manguean languages, as the internal linguistic diversity of this phylum from the Americas displays almost all types. From the lexical end of the continuum, where grammatical affixes receive their own lexical tone, to the morphosyntactic end, where tone works as a regular exponent of a given grammatical category, there are at least five other types; each one with its own logic.

We are at the dawn of understanding how complex systems work. But to do better we need help. We need full paradigms in grammars of tonal languages, not just rules, abstract representations or examples of how a given form bearing tone is used in a natural context. This is a cordial invitation to descriptive linguists to enrich the field with new data on inflection. It matters. It matters in a time when most languages with complex morphology are 
dying. By doing so, we will be paying tribute both to the languages and to the field of linguistics, because in a hundred years from now, when all of us are gone, it will only be our data that shall remain for future linguists to continue increasing our understanding of our human languages.

\section{Acknowledgements}

This paper was supported by the ESRC/AHRC project ES/I029621/1 "Endangered Complexity: Inflectional classes in Oto-Manguean languages". I thank Jean-Léo Léonard for comments on an earlier version of this typology. I am heartily grateful to Timothy Feist for accepting reviewing this paper with a short notice and for all the comments and suggestions that have contributed a lot to its improvement. Thanks to the anonymous referee for suggesting that a paper like this should be included in the volume.

\section{References}

de Angulo, Jaime. 1933. The Chichimeco language (Central Mexico). International Journal of American Linguistics 7-3/4: 152-194.

Aronoff, Mark. 1994. Morphology by itself: Stems and inflectional classes. Cambridge, MA: MIT Press.

Baerman, Matthew and Enrique L. Palancar. 2014. Baerman, Matthew and Enrique L. Palancar. 2014. The organization of Chinantec tone paradigms. Carnets de Grammaire 22 [Proceedings of the Décembrettes, 8th International conference on morphology], 46-59.

Bonami, Olivier and Ana R. Luís. 2014. Sur la morphologie implicative dans la conjugaison du portugais : une étude quantitative. Mémoires de la Société de Linguistique de Paris, Vol. 22: 111-151.

Bonami, Olivier and Gilles Boyé. 2007. Remarques sur les bases de la conjugaison, in Elisabeth Delais-Roussarie and Laurence Labrune (eds.), Des sons et des sens, pp. 7790. Paris: Hermès.

Campbell, Lyle, Terrence Kaufman, and Thomas C. Smith-Stark. 1986. Meso-America as a linguistic area. Language 62:530-70.

Campbell, Lyle. 1997. The historical linguistics of Native America. [Oxford Studies in Anthropological Linguistics, 4]. Oxford: Oxford UP: Oxford University Press.

Creisels, Denis, Anderson M. Chebanne, and Heather W. Nkhwa. 1997. Tonal Morphology of the Setswana Verb. München: Lincom Europa.

Creisels, Denis. 2006. Tswana verb morphology and the lexical integrity principle. Lingue e Linguaggio 5:1, 1-18.

DiCanio, Christian T., Jonathan Amith and Rey Castillo García. 2012. Phonetic alignment in Yoloxóchitl Mixtec. Paper read at the 2012 meeting of the Society for the Study of the Indiginenous Languages of America, Portland.

Finkel, Raphael and Gregory Stump. 2009. Principal parts and degrees of paradigmatic transparency, in James P. Blevins and Juliette Blevins (eds.), Analogy in Grammar: Form and Acquisition, pp.13-53. Oxford: Oxford University Press.

Finkel, Raphael and Gregory T. Stump. 2007. Principal Parts and Morphological Typology. Morphology 17-1: 39-75.

Foris, David Paul. 2000. A grammar of Sochiapam Chinantec [Studies in Chinantec Languages 6]. Dallas, TX: SIL International and the University of Texas at Arlington.

Hernández Green, Néstor. 2015a. Acazulco Otomi, in Timothy Feist and Enrique L. Palancar. The Oto-Manguean inflectional class database. University of Surrey. $<$ www.smg.surrey.ac.uk/oto-manguean> 
Hernández Green, Néstor. 2015b. Morfosintaxis verbal del otomí de Acazulco. Unpublished $\mathrm{PhD}$ thesis in Indoamerican Linguistics at the Centre for Research and High Studies in Social Anthropology (CIESAS), Mexico.

Hernández-Green, Néstor. Forthcoming. The inflectional classes of Acazulco Otomi, in Enrique L. Palancar, Matthew Baerman, and Timothy Feist (eds.), Inflectional complexity and verb classes: New facts from the Oto-Manguean languages of Mexico.

Levy, Paulette. 1987. 'La irregularidad en otomangue'. Plenary talk given at I Coloquio Internacional "Mauricio Swadesh". Mexico D.F.

Merrifield, William R. 1968. Palantla Chinantec grammar [Papeles de la Chinantla 5, Serie Científica 9]. Mexico City: Museo Nacional de Antropología.

Merrifield, William. R. and A. E. Anderson. 2007. Diccionario Chinanteco de la diáspora del pueblo antiguo de San Pedro Tlatepuzco, Oaxaca. [2nd Edition] [Serie de vocabularios y diccionarios indígenas "Mariano Silva y Aceves" 39]. Mexico DF: Summer Linguistic Institute.

Montermini, Fabio and Olivier Bonami. 2013. Stem spaces and predictability in verbal inflection, Lingue e linguaggio 12: 171-190.

Morin, Yves-Charles. 1987. Remarques sur l'organisation de la flexion en français, International Review of Applied Linguistics 77-78: 13-91.

Pace, W. J. 1990. Comaltepec Chinantec verb inflection, in W. R. Merrifield and C. R. Rensch (eds.), Syllables, tones and verb paradigms [Studies in Chinantec Languages 4], 21-62. Arlington, Texas: The Summer Linguistic Institute and the University of Texas at Arlington

Palancar, Enrique L. 2014. Revisiting the complexity of the Chinantecan verb conjugation classes, in Jean-Léo Léonard and Alain Kihm (eds.), Issues in Meso-American morphology, pp. 77-102. Paris: Michel Houdiard.

Palancar, Enrique L. and Heriberto Avelino. Forthcoming. Inflectional complexity and verb classes in Chichimec, in Enrique L. Palancar, Matthew Baerman, and Timothy Feist (eds.), Inflectional complexity and verb classes: New facts from the Oto-Manguean languages of Mexico.

Pike Kenneth. 1948. Tone languages: A technique for determining the number and types of pitch contrasts in a language, with studies in tonemic substitution and fusion. Ann Arbor: University of Michigan Press.

Rasch, Jeffrey. 2015. Yaitepec Chatino, in Timothy Feist and Enrique L. Palancar. The OtoManguean inflectional class database. University of Surrey. $<$ www.smg.surrey.ac.uk/oto-manguean>

Roberts, David. 2013. Conjugaison des verbes en kabiyè (Togo): Tableaux types, règles d'emploi, et index kabiyè-français et français-kabiyè des verbes. Paris: L'Harmattan.

Suárez, Jorge A. 1983. La Lengua Tlapaneca de Malinaltepec. Mexico City: Instituto de Investigaciones Filológicas, Universidad Nacional Autónoma de México. 
APPENDIX

Table 14. Tonal paradigms in Yaitepec Chatino.

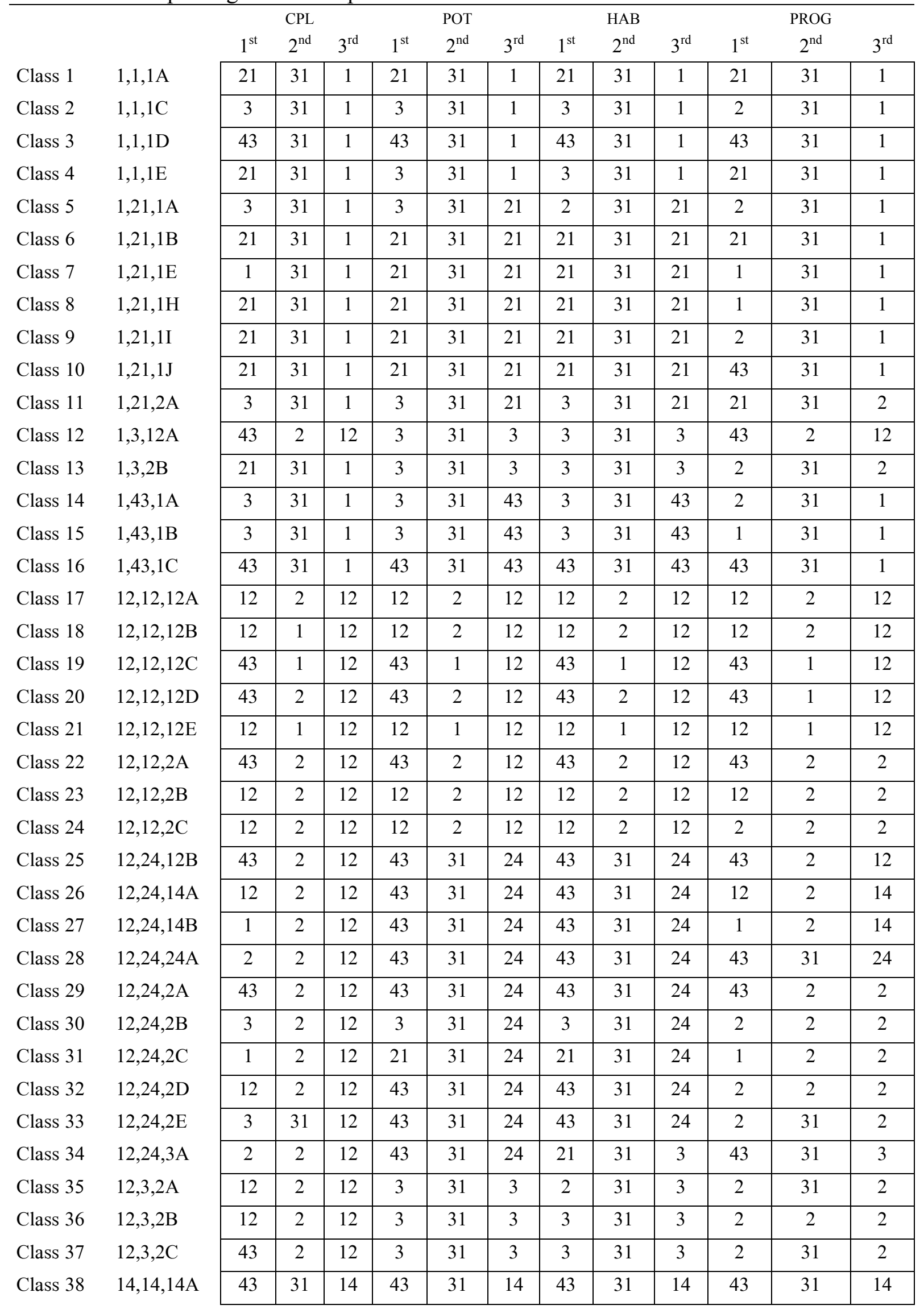




\begin{tabular}{|c|c|c|c|c|c|c|c|c|c|c|c|c|c|}
\hline Class 39 & $2,2,2 \mathrm{~A}$ & 2 & 31 & 2 & 2 & 31 & 2 & 2 & 31 & 2 & 2 & 31 & 2 \\
\hline Class 40 & $2,2,2 \mathrm{~B}$ & 2 & 2 & 2 & 2 & 2 & 2 & 2 & 2 & 2 & 2 & 2 & 2 \\
\hline Class 41 & $2,24,14 \mathrm{~A}$ & 2 & 2 & 2 & 43 & 31 & 24 & 43 & 31 & 24 & 43 & 2 & 14 \\
\hline Class 42 & $2,24,14 \mathrm{~B}$ & 1 & 31 & 2 & 43 & 31 & 24 & 43 & 31 & 24 & 43 & 31 & 14 \\
\hline Class 43 & $2,3,14 \mathrm{~A}$ & 2 & 2 & 2 & 43 & 31 & 3 & 43 & 31 & 24 & 2 & 2 & 14 \\
\hline Class 44 & $21,21,1 \mathrm{~A}$ & 21 & 31 & 21 & 21 & 31 & 21 & 21 & 31 & 21 & 21 & 31 & 1 \\
\hline Class 45 & $21,21,21 \mathrm{~A}$ & 21 & 31 & 21 & 21 & 31 & 21 & 21 & 31 & 21 & 21 & 31 & 21 \\
\hline Class 46 & $23,23,12 \mathrm{~A}$ & 23 & 1 & 23 & 23 & 1 & 23 & 23 & 1 & 23 & 12 & 1 & 12 \\
\hline Class 47 & $23,23,12 \mathrm{D}$ & 43 & 1 & 23 & 43 & 1 & 23 & 43 & 1 & 23 & 43 & 1 & 12 \\
\hline Class 48 & $23,23,23 \mathrm{~A}$ & 43 & 1 & 23 & 43 & 1 & 23 & 43 & 1 & 23 & 43 & 1 & 23 \\
\hline Class 49 & $23,24,12 \mathrm{~A}$ & 43 & 1 & 23 & 43 & 31 & 24 & 43 & 31 & 24 & 43 & 1 & 12 \\
\hline Class 50 & $23,24,12 \mathrm{~B}$ & 23 & 1 & 23 & 43 & 31 & 24 & 43 & 31 & 24 & 12 & 1 & 12 \\
\hline Class 51 & $23,24,12 \mathrm{C}$ & 1 & 1 & 23 & 21 & 31 & 24 & 21 & 31 & 24 & 1 & 1 & 12 \\
\hline Class 52 & $23,24,12 \mathrm{D}$ & 1 & 1 & 23 & 43 & 31 & 24 & 21 & 31 & 24 & 1 & 1 & 12 \\
\hline Class 53 & $23,24,23 \mathrm{~A}$ & 23 & 2 & 23 & 43 & 31 & 24 & 43 & 31 & 24 & 43 & 2 & 23 \\
\hline Class 54 & $23,24,24 \mathrm{~A}$ & 23 & 1 & 23 & 43 & 31 & 24 & 43 & 31 & 24 & 43 & 31 & 24 \\
\hline Class 55 & $24,24,14 \mathrm{~A}$ & 43 & 31 & 24 & 43 & 31 & 24 & 43 & 31 & 24 & 43 & 31 & 14 \\
\hline Class 56 & $3,2,2 \mathrm{~A}$ & 2 & 31 & 3 & 3 & 31 & 2 & 3 & 31 & 3 & 2 & 31 & 2 \\
\hline Class 57 & $3,3,2 \mathrm{~A}$ & 3 & 31 & 3 & 3 & 31 & 3 & 3 & 31 & 3 & 2 & 31 & 2 \\
\hline Class 58 & $3,3,2 \mathrm{~B}$ & 1 & 31 & 3 & 21 & 31 & 3 & 21 & 31 & 3 & 1 & 31 & 2 \\
\hline Class 59 & $3,3,2 \mathrm{C}$ & 21 & 31 & 3 & 21 & 31 & 3 & 21 & 31 & 3 & 21 & 31 & 2 \\
\hline Class 60 & $3,3,2 \mathrm{D}$ & 3 & 31 & 3 & 3 & 31 & 3 & 3 & 31 & 3 & 2 & 2 & 2 \\
\hline Class 61 & $3,3,2 \mathrm{E}$ & 1 & 31 & 3 & 43 & 31 & 3 & 43 & 31 & 3 & 43 & 31 & 2 \\
\hline Class 62 & $3,3,2 \mathrm{~F}$ & 3 & 31 & 3 & 3 & 31 & 3 & 3 & 31 & 3 & 3 & 31 & 2 \\
\hline Class 63 & $3,3,3 \mathrm{~A}$ & 21 & 31 & 3 & 21 & 31 & 3 & 21 & 31 & 3 & 21 & 31 & 3 \\
\hline Class 64 & $3 /, 24,12 \mathrm{~A}$ & 31 & 1 & 31 & 43 & 31 & 24 & 43 & 31 & 24 & 12 & 1 & 12 \\
\hline Class 65 & $3 /, 24,12 \mathrm{C}$ & 43 & 1 & 31 & 43 & 31 & 24 & 43 & 31 & 24 & 43 & 1 & 12 \\
\hline Class 66 & $3 /, 24,24 \mathrm{~A}$ & 1 & 1 & 31 & 21 & 31 & 24 & 21 & 31 & 24 & 21 & 31 & 24 \\
\hline Class 67 & $3 /, 24,3 / \mathrm{A}$ & 43 & 1 & 31 & 43 & 31 & 24 & 43 & 31 & 24 & 43 & 1 & 31 \\
\hline Class 68 & $3 /, 24,3 / \mathrm{B}$ & 1 & 1 & 31 & 21 & 31 & 24 & 21 & 31 & 24 & 1 & 1 & 31 \\
\hline Class 69 & $3 /, 24,3 / \mathrm{C}$ & 21 & 1 & 31 & 21 & 31 & 24 & 21 & 31 & 24 & 21 & 1 & 31 \\
\hline Class 70 & $3 /, 24,3 / \mathrm{D}$ & 31 & 1 & 31 & 43 & 31 & 24 & 43 & 31 & 24 & 31 & 1 & 31 \\
\hline Class 71 & $3 /, 24,3 / \mathrm{E}$ & 43 & 1 & 31 & 43 & 31 & 24 & 43 & 31 & 24 & 31 & 1 & 31 \\
\hline Class 72 & $3 /, 3 /, 3 / \mathrm{A}$ & 31 & 1 & 31 & 31 & 1 & 31 & 31 & 1 & 31 & 31 & 1 & 31 \\
\hline Class 73 & $3 /, 3 /, 3 / \mathrm{B}$ & 43 & 1 & 31 & 43 & 1 & 31 & 43 & 1 & 31 & 43 & 1 & 31 \\
\hline Class 74 & $1,21,1 \mathrm{~A}$ & 21 & 31 & 1 & 3 & 31 & 21 & 21 & 31 & 21 & 21 & 31 & 1 \\
\hline Class 75 & $1,21,1 \mathrm{~B}$ & 3 & 31 & 1 & 21 & 31 & 21 & 21 & 31 & 21 & 2 & 31 & 1 \\
\hline
\end{tabular}

